\title{
1574
}

多

$$
\mathrm{fl}^{4}
$$

$A$

\section{TRACE ELEMENT ANALYSIS AT THE \\ LIVERMORE POOL-TYPE REACTOR \\ USING NEUTRON ACTIVATION TECHNIQUES}

R. C. Ragaini

R. Ralston

D. Garvis

June 23, 1975

Prepared for U.S. Energy Research \& Development

Administration under contract No. W-7405-Eng-48

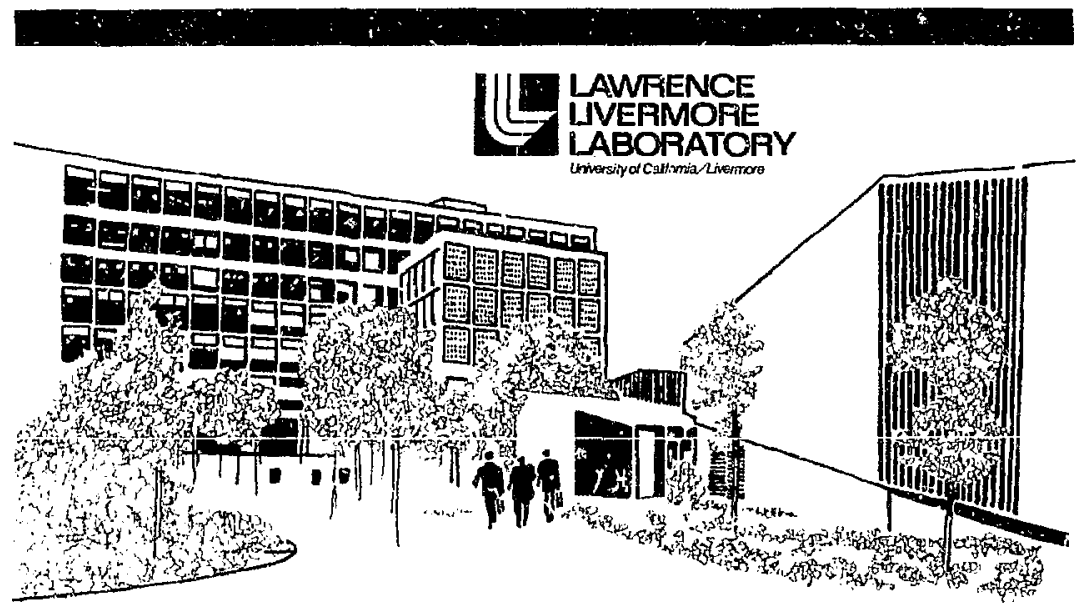


NOTICE

"This report was prepared as an uccount of work sponsored by the United States Government. Neither the United States nor the United States Energy Research \& Development Administration, nor any of their employees, not any of their contractors, subcontractors, or thelr employees, makes any wartanty, express or inplied, or assumes afy legt! liability or responsibility for the accuracy, completeness or usefutness of ar: information, apparatus, product cr process cisclosed or represents that ita we would not infringe privately-owned rights."

Printed in the United States of America Available from

National Technical Information Service

U.S. Department of Commerce

5285 Port Royail Road

Springfield $_{s}$ Virginia 22151

Price: Printed Copy $\$$

*; Microfiche $\$ 2.25$

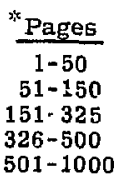

NTIS

Selling Pnice

$\$ 4.00$

$\$ 5.45$

$\$ 7.60$

$\$ 10.60$

501-1000

$\$ 13.60$ 


\section{노 \\ LAWRENCE IVERMORE LABORATOAY}

Uniersity or Caboria, Lvomare, Cafitomia 94550

UCRL 151855

\section{TRACE ELEMENT ANALYSIS AT' THE LIVERAORE POOL-TYPE REACTOR USING NEUTRON ACTIVATION TECHNIQUES}

R. C. Ragaini
R. Ralston
D. Garvis

MS. date: June 23, 1975

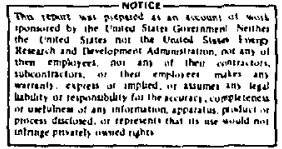




\section{Contents}

Abstract . . . . . . . . . . . . . . . . . . . . . 1

Introduction .............................. 1

Scope of Trace Element Analyals..................... I

Description of the Technique ....................... 2

Bastc Principles ....................... . . 2

Irradiation of the Coututing Procedure ................ 3

Neutran Source....................... 4

Detector Systens ...................... 4

Detection Linits . . . . . . . . . . . . . . . . . 7

standardization ...................... 7

Data Reduction ......................... 10

Degcription of GaMANAl ..................... 10

Typical Dutput from INAA Sample . . . . . . . . . . . . 12

Sample Preparation and Hendling ................... 12

Sample Geometry ..................... 13

Llquid Samples ........................ 16

Solld Samples ......................... 16

Sample Size ........................ 16

Validation .............................. . . 17

NBS Orchard Leaveg ......................... 17

EPA-NBS Intercomparieon Samples of Coal Dust and Fly Ash . . . . . . . 17

Interlaborgtory Comparioon of Standard Samplea . . . . . . . . . . 20

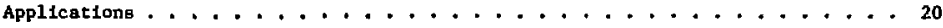

Trace Elements in Aerosolo ................... 20

The California Aerosol Characterization Experiment (ACHEX) . . . . 20

Air Sampling in the Victnity of Mining and Sqelting Operations . . . . 23

Soll and Vegetation Trace Metal Contamination Near $Z_{1 n c}$ and Lead

smelters.......................... 24

Uptrke of Trace Elements by Vegetable Grown In Livermore Treatment Plant

sludge ................................. 24

INAA of Marine Sampleg Developed In the Marine Studies Prngram . . . . . 29

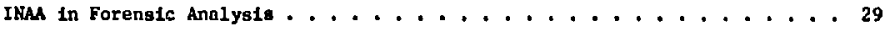

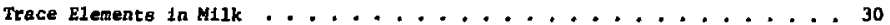

References .................................. 32 


\title{
TRACE ELEMENT ANALYSIS USING NEUTRON ACTIVATION TECHNIQUES
}

\begin{abstract}
Instrumental Neutron Activation Analysis is a technique of trace analysis using measurements of radioactivity induced In the sample by exposure to a source of neutrons. The 1aduced activity is peasured by detecting the enitted gauma radiation. Each Gama enitter can then be identified by the energy of the photc peaks produced as the muclide decays toward its ground state,

and by the half-life of the neutron-induced activicy. A complex computer program, GAMANAL, has been used which ean accomplish the major tasks of nuclide 1dentification and quantification. A description of the methods employed at the Livermore PoolType Reactor (LPTR) is discussed, Including sample preparation, 1rradiation, analyeis, and application of the technique.
\end{abstract}

\section{Introduction}

The purpose of this repore 18 to describe the capabilities of Trace Element Analysis at che Livernore Pool Type Reactor (LPTR) using Instrumental Neutron Activacion Analysis (INAS). The technology and the methode employed wili be discussed, including sample preparation, irradiation, and analyals. Applications of the INAA rechnique in pase and current projecta will be described.

SCOPE OF TRACE ELEMENT ANALYSIS

Trace elemeut analysis at the LPTR has been primarily conserned with research programs. The involvement tukes place at various level of interaction; from definition of problem through finiehed reports. In addition, a service is provided within the Laboratory for trace element analyale. The usars of the eervice are given as much eseistance se desired. Applied research and developgent contracts are also carried out with groups outolde the Laboratory. Some areas that have been Investigated are:

1. Trace elemente in aerogols

a. Alr sampling in the vicinity of gmelting operations in Kellogs, Idaho'

b. ACHEX (California Aerosol Characterization Experiment) ${ }^{2}$

2. Trace elemente in pilik

3. Trace elements in environmental samples

a. So1le/sedimente/sludge ${ }^{3}$

b. Vegetation

c. Wat'r - fresh/marine

4. Trace diements in marine organiens

5. Forensic analysio

a. Jewelry togging for Identification

b. Dismond tagging

c. Gunshot residue allalysis

Some of these projecte are described In the section on applications. 


\section{Description of the Teci:nique}

The INAA method of iruce vlement Identification has become increselagly more Important with the progressive inprovement in sensitivity. This improved senaltivity has been made posalble by the use of high-reeolution, oolid-stete radiation detectors, inproved data-collection and data-reduction techniquco, and Increased experience in sample preparation and collection methods.

Dne of the chief advantages of IKA is that it is usually a non-degtructive analytical techaique which requires little or no chemical pre-treatment. It also providee the ability to look at IBotopic concentrations as well ar elmental concentratione for Bone 18otopes. The word "Instrumental" in ch1g context means that elemeat or lootope Idencification to accomplished by instruments withowt resorting to chemical separation.

Most INAA is done using thermal neutrons from a ruclear reactor. Neutron Eluxes of $10^{12}$ to $10^{14} \mathrm{n} / \mathrm{cm}^{2} / \mathrm{sec}$ (neutrons per square centineter per second) can be easily obtalned at most reactor facilit 1es. wth fluxes of $10^{26} \mathrm{n} / \mathrm{cm}^{2}$ obtuinable at sone of the pulsed research reactor factllt1es. However, pulsed reactor fluxes àre ueeful only when looking at elements with Induced activitleg having half-lives on the order of tenths-of-geconds. Recently some INAA has been performed using ${ }^{252} \mathrm{Cf}$ sources with fast neutrons having energies up to $14 \mathrm{MeV}$.

\section{BASIC PRINCIPLES}

Instrumenial neucron activation analysis is based on the measurement of radioactivity induced in the sample after exposure to a source of neucrons. Th1s Induced activity is nost easily determined by detecting the eattked gama radiation wth a gamma gpectrometer which character1zes the gamma emlastans present. Thts characterization gives the energy and aboolute intensity of each gamm ray. Figure 1 is a Bchematic repreeentation of the wethod.

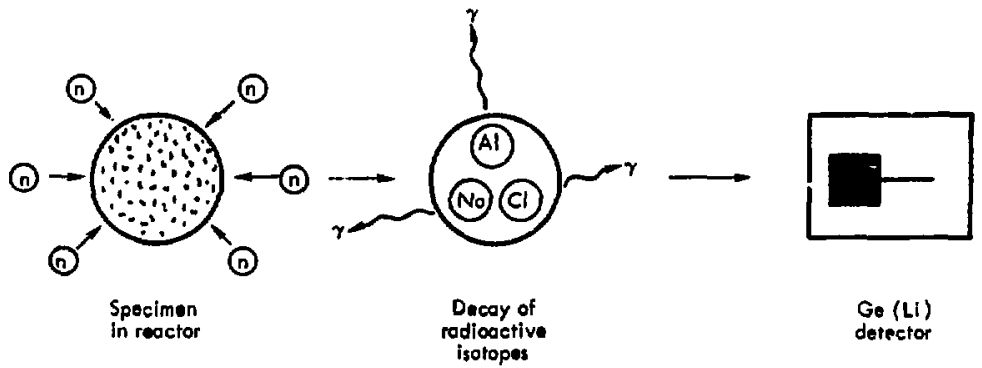

F18. 1 Schematic diegram of Inetrumentel Neutron Activation Analyalo Procedire. 
Once the gama spectrum is obtained, 1t 18 recessary to Identify the mixture of nuclides which will account for the complex spectrum. Each gamma emitter can be 1denctfled by the energy (or energies) of the photopeaks produced as the nuclide decays towards 1 s ground state, and by the half-1ife of the neutron-1nduced act1vicy. Most elements which have a useful cross-aection for neutron capture, produce at least one 1sotope which can be used for a unlque identification based on half-life and game peaks. A complex computer proBram has been devaloped which can acconplish the major tasks of nuclide identif 1cation aud quantilation. This program, GAMNAL, w111 be discuased later.

The Identification of the nuclide present in an activated sample does not immediacely yield an clemental analyais in a useful form. It is necessary to tranglate absolute information, such as diafintegrations per minute or atoms present at zero timL, Into parts per million, or total ng, etc. This can be accomplished in ewo ways. The first would involve calculations baged on measured neutron flux, cross-gections, and exposere times. This Is fundamentelly posglble, bur is :ntally dependent on precise knowledge of a numher of gacured parameters. Thus, the cunulat1ve uncertainties of a large number of neacuremente mokes the final annuer quite unrellable. The second method is to stwultaneoualy 1rradiats a mixture of known asounts of the elemente in question and to deteruine the unknown by direct ratio of activitles. Tuis method has the advantage of being independent of any absolute messurements, and in addition, gives an andyalo of the natural element rather than Individual 1sotopea as in the firet method. A second computer progran hes been developed to take the daca produced by GAMANal and produce the final analyas based on the aecond method.

In most, if not all samples, there are competing activitles to be considered. The samples usually contain many trace elemencs as well as the princ1ple ones. The activation and counting scheme employed mis:; be chosan In auch a manner as to opetmize the activity of at wany eleaente a reasonably posstile. This usually involvea making two or more separete irradiation: for each sample, and applying varlous counting achedules depending on the type of sample and the elecents boing sought in the andyais. This is an effective anthod of utillaing the half-lives to ueparate elements Into groups, thus reducing the complexity of the spectral atx and producIng $1 \mathrm{ess}$ anblguous 1dent1flcations. In addition, a strong Interference produced by - major component auch as aodium can be allowed to die away leaving the lonjer lived trace elements orili amenable to analya1s.

\section{IRRADLATION AND COUATING PROCEDURE}

A typical Irradiation schedule and counting acheme 18 discused in detail below.

The terms $Q 1$ and $Q 2$ refer to the flat and second count (respectively) after the ghort Irradiation, and L1, L2, L3 likewlee refer to the long irradiation.

The Irradiation and counting achene (Table 1) was designed to stve the maxima. rensitivity for a wide range of elements. The scheare 1s aimilar to that used by others for the same type of analyses. 
Table 1. Neucron-1rradiation and sample-counting ecbedule.

\begin{tabular}{|c|c|c|c|c|}
\hline $\begin{array}{l}\text { Irrad lat lon } \\
\text { time }\end{array}$ & $\begin{array}{l}\text { Neutrgn: ilux } \\
\left(\mathrm{n} / \mathrm{cm}^{2} / \mathrm{sic}^{2} \mathrm{c}\right)\end{array}$ & $\begin{array}{c}\text { Cooling } \\
\text { time }\end{array}$ & $\underset{t \text { Count }}{\text { Cong }}$ & $\begin{array}{l}\text { Elements } \\
\text { detectod }\end{array}$ \\
\hline $2 \mathrm{~m} i \mathrm{n}$ & $2 \times 10^{13}$ & $\begin{array}{l}4 \min \\
20 \min \end{array}$ & $\begin{array}{l}500 \text { sec } \\
1000 \text { sec }\end{array}$ & $\begin{array}{l}\text { M, v, Cu, T, Gil } \\
\text { Na, M, } \because, \mathrm{Mn}, \mathrm{Br}, \\
\text { 1, Ba, In }\end{array}$ \\
\hline $12 \mathrm{rr}$ & $4 \times 10^{12}$ & $\begin{array}{l}20-30 \mathrm{hr} \\
6-10 \text { days } \\
20-30 \text { days }\end{array}$ & $\begin{array}{l}2000 \mathrm{sec} \\
100 \mathrm{mln} \\
8-12 \mathrm{hr}\end{array}$ & $\begin{array}{l}\text { As, K, Ga, K, ld } \\
\text { Sm, Au, Ha, La, Sb } \\
\text { Ft, Cr, Co, ln, HR, } \\
\text { Se, Ag, Sb, Ce, liu, } \\
\text { Si, Th, Nl, Ta, Hf, } \\
\text { Ba, Rb }\end{array}$ \\
\hline
\end{tabular}

The data derived are recorded on computer-compatihle magnetlc tape far permanent reference ard for subsequent reduction and analysis. The procedure 10 effective for the idencifieation of 35 elements in a single sample.

Table 2 gives a listing of thu parent nuclide, half-life, daughter product, and enerby of the gama rays used in the anajysis of che elemencs of tuterest. It shows that ${ }^{65}$ zn hes a gama ray with an energy of $1115.4 \mathrm{keV}$. Thus, If there are Jargo amounts of both $\mathrm{Zn}$ and $S c$ in a sample 1t any not be possible to separate the gamas ray peake gince they would overlap when using detectors wth resolutions that are currently avallable. Scandiut has another gama ray with an energy of 889.4 keV, and the only approciable interference with this peaik is the $110_{A B}$ ganma ray at $8 B 4.7 \mathrm{keV}$. By the use of the GAMANAL program, 1t 1 a posesble to resolve large amounte of ${ }^{110 \mathrm{~m}} \mathrm{As},{ }^{46} \mathrm{Sc}$, and ${ }^{65} 7 \mathrm{n}$ in the aame ample. A closo examitation of Table 2 reveals oeveral other Interferences of the type discuaned above which occur in a typical eample.
The Neutron Source

The neutron source issed to activate samples 19 che Livermor: Pool Type Reactor (LPTR) which 18 a $11 \mathrm{ght}$-water moderated and cooled reactor conatsing of plate-type fuel elements and boron-containing control rods located in a $7.9 ;(26 \mathrm{fc}$ ) detp by $1.98 \mathrm{~m}(\dot{0}, 5 \leq t)$ Jlaneter tank. Varisug ban cubes and Irradiacion facilities allow access to neutron fluxes ranging as intgh as $7 \times 10^{13} \mathrm{n} / \mathrm{cm}^{2} / \mathrm{sec}$, and gamma doae rates above $10^{10} \mathrm{rad} / \mathrm{hr}$. The reactor is used for beaic and appiict research in eupport of Laboratory programs. The reactor it c perated cn a echeduled basis thac permits a coutine maintenance period, standard safety oystem checks, and a maximum cperating schedule for oxperiments and Irradiations. The LPTR's User's Guide" describeg the experitontal frradiation faclities and aervices that are avallable.

\section{The Detector Syatem}

The ability to analyze the samples, orice they have been irrad lated, 1a of primary Impor tance. 
Table 2. Parent, daughter, half-life, and energy of oboerved gamra rays for elementa analyzed by LNAA at the LPTR.

\begin{tabular}{|c|c|c|c|}
\hline $\begin{array}{l}\text { Parent } \\
\text { c lement } \\
\text { exposed }\end{array}$ & $\begin{array}{l}\text { Danghter } \\
\text { tsocope } \\
\text { observed }\end{array}$ & Half -1 if $e^{\prime \prime}$ & $\begin{array}{c}\text { Gilmma-ray energy observed } \\
\text { (kev) }\end{array}$ \\
\hline$T i$ & ${ }_{22}^{51} \mathrm{Ti}$ & $5.79 \mathrm{~m}$ & $320.0(100)$ \\
\hline $\mathrm{Mg}$ & $\frac{27}{12} \mathrm{Mg}$ & $9.46 \mathrm{~m}$ & $843.8(100), 1014.5(37.5)$ \\
\hline Cu & ${ }_{29}^{66} \mathrm{Cu}$ & $5.10 \mathrm{~m}$ & $1039.2(100)$ \\
\hline$y$ & $\frac{32}{2 \cdot 3}$ & $3.75 \mathrm{~m}$ & $1434.3(100)$ \\
\hline $\mathrm{Ai}$ & 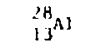 & $2.32 \mathrm{~m}$ & $1778.7(100)$ \\
\hline$r^{2}$ & $2_{20}^{49} \mathrm{Cn}$ & $8.80 \mathrm{~m}$ & $3084.4(100)$ \\
\hline M.1 & ${ }_{534}^{134} \mathrm{Ba}$ & $82.9 \mathrm{~m}$ & $165.8(100)$ \\
\hline 1 & $53^{128}$ & $25.0 \mathrm{~m}$ & $443.3(100), 526.4(9.9)$ \\
\hline $\mathrm{Hr}$ & ${ }_{3}^{\mathrm{ho}} \mathrm{Kr}$ & $16.8 \mathrm{gl}$ & $616.2(100), 665.6(17.2)$ \\
\hline in & $\operatorname{lin}_{49}^{16 n}$ & $53.7 \mathrm{~m}$ & $417.0(40.2), 1097.1(59.8), 1293.4(100)$ \\
\hline S.. & $24 \mathrm{Na}$ & $15.0 \mathrm{~h}$ & $1368.4(100), 2754.1(100)$ \\
\hline $\mathrm{Cl}$ & ${ }_{17}^{38} \mathrm{Cl}$ & $37.3 \mathrm{~m}$ & $1642.7(74.5), 2167.6(100)$ \\
\hline Mn & 259 & $15.0 \mathrm{~m}$ & $846.7(100), 1811.2(29.4)$ \\
\hline is & $33^{A . A}$ & 26.4 & $559.1(100), 657.1(100)$ \\
\hline$w$ & ${ }_{74}^{187} \mathrm{~W}$ & $23.9 \mathrm{~h}$ & $: 34.2(31.6), 479.5(83.1), 618.2(23.1), 685.7(100)$ \\
\hline Ta & ${ }_{31}^{72} \mathrm{con}$ & 14.1 & $629.9(25.5), 834.0(100), 22016(27.3)$ \\
\hline * & ${ }_{19}^{42} \mathrm{~K}$ & 12.4 & $1524.7(100)$ \\
\hline Cd & ${ }_{4.3}^{115} \mathrm{Cd}$ & 53.5 & $492.3(29.5), 527.9(100)$ \\
\hline $\sin$ & ${ }_{63}^{133} \mathrm{Sm}$ & 46.8 & $103.2(100)$ \\
\hline Au & ${ }_{79^{A U}}^{198}$ & 64.7 & $411.8(100)$ \\
\hline
\end{tabular}


Table 2, (Cont inued)

\begin{tabular}{|c|c|c|c|c|}
\hline $\begin{array}{l}\text { Parent } \\
\text { el ement } \\
\text { exposed }\end{array}$ & $\begin{array}{l}\text { Daughter } \\
\text { isotope } \\
\text { observed }\end{array}$ & Halti -1 & $110^{4}$ & $\begin{array}{c}\text { Gamba-ray energy ubserved } \\
(k \in V)\end{array}$ \\
\hline $\mathrm{La}$ & ${ }_{57}^{140} \mathrm{La}$ & 40.2 & $\mathbf{h}$ & $328.8(21.4), 487.0(49.4), 1596.6(100)$ \\
\hline $\mathrm{Fe}$ & ${ }_{26}^{59} \mathrm{Fe}$ & 45.6 & d & $1099.3(100), 1291.5(77.0)$ \\
\hline $\mathrm{Cr}$ & ${ }_{2 i}^{51} \mathrm{Cr}$ & 27.8 & d & $320.1(100)$ \\
\hline Co & ${ }_{27}^{60} \mathrm{Co}$ & $5.2 \mathrm{~h}$ & $y^{*}$ & $1173.2(100), 1332.5(100)$ \\
\hline $7 . n$ & ${ }_{30}^{65} \mathrm{Zn}$ & 26.3 & d & $1115.5\left(10^{9}\right)$ \\
\hline $\mathrm{Hg}$ & ${ }_{80}^{203} \mathrm{Hg}$ & 45.9 & d & $279.2(100)$ \\
\hline $\mathrm{Se}$ & ${ }_{34}^{73} \mathrm{Se}$ & 120. & $d$ & $136.0(96.0), 264.7(100)$ \\
\hline${ }^{3} B$ & $\operatorname{lng}_{47}^{108 m} \mathrm{Ag}$ & 5.00 & $y$ & $434.0(100), 614.4(100), 723.0(100)$ \\
\hline $\mathrm{Ag}$ & ${ }_{47}^{110 m}$ & 255 & $d$ & $6.7 .7(100), 884.7(79.6), 937.5(36.5), 1387.2(27.7)$ \\
\hline $\mathrm{sb}$ & ${ }_{51}^{i 24} \mathrm{Sb}$ & 60.3 & $d$ & $602.7(100), 1691.3(5 . .2)$ \\
\hline $\mathrm{Ce}$ & ${ }_{58}^{141} \mathrm{Ce}$ & 32.5 & d & $145.5(100)$ \\
\hline Eus & ${ }_{63}^{152} \mathrm{Eu}$ & 12.7 & $y$ & $121.8(100), 3.4 .2(85.6), 1408.1(65.0)$ \\
\hline Sc & ${ }_{21}^{46} \mathrm{Sc}$ & 83.9 & $d$ & $889.3(100), \quad: 120.5(100)$ \\
\hline Th & ${ }_{91}^{233} \mathrm{~Pa}$ & 27.0 & d & $311.9(100)$ \\
\hline N1 & $27^{58} \mathrm{Co}$ & 71.3 & d & $811.1(100)$ \\
\hline thf & ${ }_{72}^{175} \mathrm{Hf}$ & 70.0 & d & $343.4(200)$ \\
\hline nif & ${ }_{72}^{181} \mathrm{He}$ & 42.3 & d & $133.1(49.4), 482.2(100)$ \\
\hline
\end{tabular}

${ }^{a}$ TId units are as follows: $n=$ minutes, $h=$ hours, $d=$ days, $y=$ years.

bumbers given in parenchesis following the gamma ray energy are the rolative intensitles (\%) of the gamina rays. 
Figure 2 is a block dlagram of the artector system for counting short irradiatjon samples. It $1 \mathrm{~s}$ bullt around a $40-$ $\mathrm{cm}^{2}$ itchium-driftad germantum Ge (L1) detector coupled to a 4096 channel pulge helght analyzer and the approprtate linear electronics.

For counting samples urbjected to long trradiation, a variacy of decectora are avallable. These are degcribed In Ref, 5. A brief sumary is given below.

The gama counting ta accomplishe? with a variety of Ge(L1)-diode detector syst ms whish are listed in Table 3 . The diodes vary in volume from 19 to 50 r.c. Three of the counting systems are automaced. The autonaced systemo, Interfaced to a PDP-8 camputer, are capable of handling 16 oamples per system, thus allowing 24-hr/ day counter use. The remalnder of the systems can analyze one sample at a time, and the daca are trangferred to the PDP-B system by a manual dump. All data are bubsequentiy transferred to magnetic tape and analyzed on a CDC-7600 computer (described later).

Figure 3 shows a typical sample changer associsted with a Ge(Li) detector system. The cryostat and detector are seen to the left of upper center while the lower balf of the picture shows the ample holders in the changer. The center of the photograph shows the mechanisa for raiaing a ample into counting position. The whole system is autoratel under control of the PDP-8 system.

The data derived using the counting scheme shown in Table 1 are recorded on computer-compacible magnetic cape far perwanent reference and for subsequent reduc- tion and analysis. The procedure is effective for the identification of 35 elenents in a single sample. other elements are added to the lise as the need artses.

\section{Detection Limiteg}

The detection linits for 75 elements are glves in Table 4 , based on a maxinum Irradiation time of $1 \mathrm{hr}$, a theral neutron flux of $10^{13} \mathrm{n} / \mathrm{cm}^{2} / \mathrm{sec}$, anc no atprectable interferences. 'These detection limfirs can therefore be thought of as theoretical 11 its within the state-of-the-art. An example of empirically derived detection imits are shown in Table 5.

\section{Standardization}

The standardization methods differ for short and long irradiatlons. The main oimllarity in the two methodg is thet both use premixed solutions ccataining only those elements of interest. Both have the same shortcoming, namely, that one must prepare standards of approximate.' $y$ the same concentrations as the sauples of interest. This necessicates en estimation of the composition of the sanple. However, this estimation 1s critical only if one is looking at samples which contain large amounts of elements that have Interfering gamme rays,

For short irradlations all samplea are normalized to a "standard flux monitor". ' veral diffierent types of lux monitors are used by difierent investigators depending on their specific application, but each is designed to do the aame thing, namely, to normalize a given irradiation back to some known condition or parameter. 


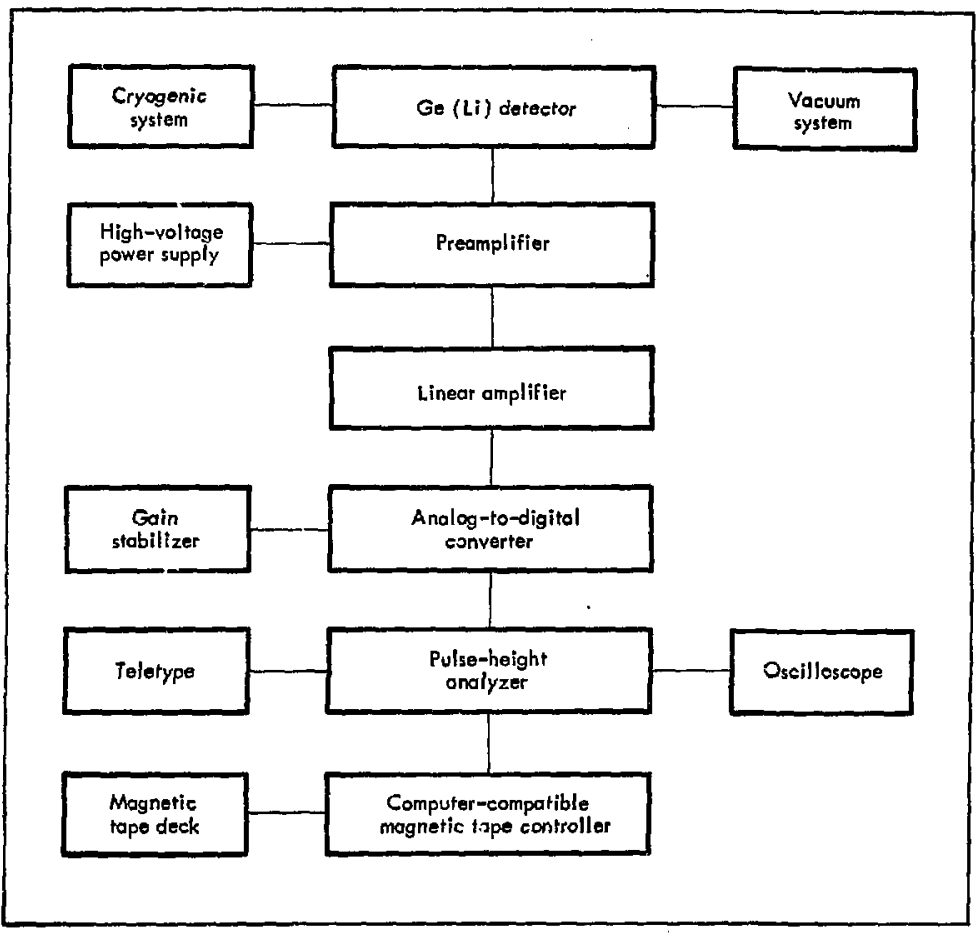

FIg. 2 Block diagram of INAA detector system used for short irradiation counting. 
Table 3. Sumpary of Ge(L1) detectors and gystems used for ganmo-counting INAA samples.

Detector and system Identification Description

\begin{tabular}{|c|c|}
\hline$C 2$ & $\begin{array}{l}\text { Canberra } 45-c e \text { "down-looker," } \\
\text { automatic counting chamber No. } 2 \text {. } \\
\text { PDP-8 control and dump. }\end{array}$ \\
\hline N1 & $\begin{array}{l}\text { Nuclear Diodes } 40-c c \text { "down-looker," } \\
\text { automatic counting chamber No. } 1 \text {," } \\
\text { PDP-8 control and dump. }\end{array}$ \\
\hline T3 & $\begin{array}{l}\text { Princeton Ganma Tech } 50 \text {-ce "down-looker," } \\
\text { autoinatic counting chamber No. } 3 \text {, } \\
\text { PDP-8 control and dump. }\end{array}$ \\
\hline S4 & $\begin{array}{l}\text { Nuclear Dtodes } 48-c c \text { "up-looker," } \\
\text { manual change., } \\
\text { PDP-8 control and dump. }\end{array}$ \\
\hline$M 5$ & $\begin{array}{l}\text { LLL } 19 \text {-cc "down-looker," } \\
\text { manual change, } \\
\text { paper tape output. }\end{array}$ \\
\hline U8 & $\begin{array}{l}\text { Nuclear Dlodes } 25-c c \text { "up-looker," } \\
\text { manual change, } \\
\text { paper tape output. }\end{array}$ \\
\hline W7 & $\begin{array}{l}\text { Nuclear Diades } 48-c c \text { "side-looker," } \\
\text { manual change, } \\
\text { paper tape output. }\end{array}$ \\
\hline v7 & $\begin{array}{l}\text { Nuclear Dlodes } 48-c c \text { "slde-looker," } \\
\text { manua1 change, } \\
\text { paper tape output. }\end{array}$ \\
\hline & $\begin{array}{l}\text { All systems except } U \text { use } 4096 \text {-channel } \\
\text { analyzers. System U uses a } 2048- \\
\text { channel analyzer. }\end{array}$ \\
\hline
\end{tabular}

A titanium flux moaltor is normelly used, and 18 counted for 60 sec between the 500and 1000-aec sample counts as shown In

Table 1. Several titanium flux monttors are In use. All were irradiated for a predetermined time, counted, and found to be atatiotically 1dentical bo they are uged interchanges?ly. The flux mon1tora are piaced in the same position, with regpect to the anple, in the oample corrier during each Irradiation. The counts from the aample flux monttor aze then proportioned to tha mater standard fIux nonttor count, and all elemental cour*s are then proportioned up or down by the same factor. The proportloning is performed by the data reduction program, and the program "flaga" any monitor that deviates from the master monitor by more than $10 \%$, thus signaling the possibility of an errar in the 1rradiation procedure elther in positioning, timing, or a shift in flux digtribution within the reactor.

To calfbrate the detector, we put a standard golution of known elemental composition on a filter paper, Irradiate 


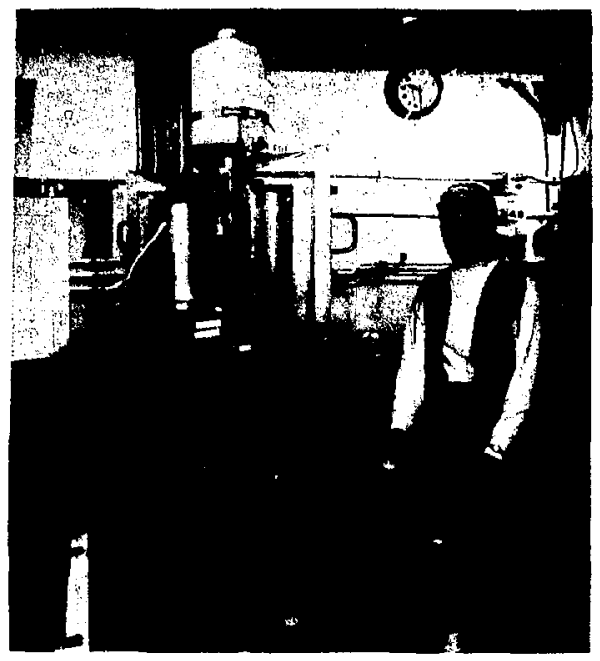

F1g. 3 Automatic sample changing syster utilizing a Ge(L1) detector.

and count the sample along with a T1 flux monicor, and cetermine the gamma-ray pesk area versug the mass for the standard aample. Enough eamples are then made up and run to produce a peak area vo sample position for each element of interest. This matrix includes boch che gtandard value as well as the anulytical error estimate for each element in the matrix.

For the long 1rradiations a otandard Is normally prepared for each irradiation. The atandard 18 then 1rradiated with and counted in the aame pastition and sequence af the sample. Any flux variation that may have existed from one irradiation to another $1 \mathrm{a}$ thereby talien Into account. Thin procedure effectively calibrates the detector for each sample run.
DATA REDUCTION

The data reduction gamma-ray analysia programs used are MIKEGAM and GAMANAL. MIKEGAM Is an adapted version of a technique developed by Ralaton and Wilcox. ${ }^{6}$ It 16 written 80 as to be run unter the sonitor Sygtem on Lawrence Ltvermore Laboratory ${ }^{\prime} 6$ CDC 6600 computers, and is used primar11y for analyots of short irradiation daca. GAKANAI 18 used for the long irradiation data reduction. The accuracy of the codes has been verifted by use of Interlaboratory and intralaboratory comporiaon studies.

\section{Degcription of GAMANAL}

The GaMANaL code to a general purpose computer program used for data reduction 
Ta:le 4. Detection 1imits of the INAA technique to 75 elements, assuming a 1-hr Irradiation with a chermal neutron $f l u x$ of $10^{13} \mathrm{n} / \mathrm{cm}^{2} \mathrm{sec}$ and no appreciable interferences.

Limit of detection (ug)

$$
\begin{array}{ll}
1-3 \times 10^{-7} & \text { Dy } \\
4-9 \times 10^{-7} & \mathrm{Eu} \\
1-3 \times 10^{-6} & \mathrm{Mn}, \mathrm{In}, \mathrm{Lu} \\
4-9 \times 10^{-6} & \mathrm{Co}, \mathrm{Rb}, \mathrm{Ir} \\
1-3 \times 10^{-5} & \mathrm{Br}, \mathrm{Sm}, \mathrm{Ho}, \mathrm{Re}, \mathrm{Au} \\
4-9 \times 10^{-5} & \mathrm{Ar}, \mathrm{V}, \mathrm{Cu}, \mathrm{Ga}, \mathrm{As}, \mathrm{Pd}, \mathrm{Ag}, \mathrm{I}, \mathrm{Pr}, \mathrm{W} \\
1-3 \times 10^{-4} & \mathrm{Na}, \mathrm{Ge}, \mathrm{Sr}, \mathrm{Nb}, \mathrm{Sb}, \mathrm{Cs}, \mathrm{La}, \mathrm{Er}, \mathrm{Yb}, \mathrm{U} \\
4-9 \times 10^{-4} & \mathrm{Al}, \mathrm{Cl}, \mathrm{K}, \mathrm{Sc}, \mathrm{Se}, \mathrm{Kr}, \mathrm{Y}, \mathrm{Ru}, \mathrm{Gd}, \mathrm{Tm}, \mathrm{Hg} \\
1-3 \times 10^{-3} & \mathrm{SI}, \mathrm{Ni}, \mathrm{Rb}, \mathrm{Cd}, \mathrm{Te}, \mathrm{Ba}, \mathrm{Tb}, \mathrm{H}, \mathrm{Ta}, \mathrm{Os}, \mathrm{P}, \mathrm{Th} \\
4-9 \times 10^{-3} & \mathrm{P}, \mathrm{TI}, \mathrm{Zn}, \mathrm{Mo}, \mathrm{Sn}, \mathrm{Xe}, \mathrm{Ce}, \mathrm{Nd} \\
1-3 \times 10^{-2} & \mathrm{Mg}, \mathrm{Ca}, \mathrm{Tl}, \mathrm{Bl} \\
4-9 \times 10^{-2} & \mathrm{~F}, \mathrm{Ne}, \mathrm{Zr}
\end{array}
$$

and Interpretation of gama spectra. It examines the pulse-height data for "backBround" and "peak" reglons, fits these peaks with the proper shape functions, and corrects for the effects of geometry. attenuation, and detector efficlency in evaluating the photon emigaton rate. The program then eearchea a "11brary" of decay-scheme information and makes tentative asigmente for each of the observed peaks. A matrix of equations 18 formed to that the Intenstty of each peak 18 desctbed as a linear addition of the Identified nuclides present. The quantitative value, ar well as the degree of Interference, is the result of a least-squares solution of this set of equations. Unlikely components are also weeded out in this process. A more complete description is glven by Gunntilk and N1day. 7

For the neutron activation analysia program, a spectal library of nuclideg is loaded Into GaMANAL. 
Table 5. Limlts of detection for trace elements in aerosols with ingtrumental neutron activation $-\mathrm{ng} / \mathrm{m}^{3}$.

\begin{tabular}{ccc}
\hline Element & $\begin{array}{c}\text { Geiman } \\
\text { GA-1 }\end{array}$ & $\begin{array}{c}\text { Impactor } \\
\text { fIlmb }\end{array}$ \\
\hline $\mathrm{Na}$ & 300 & 200 \\
$\mathrm{Hg}$ & 100 & 10 \\
$\mathrm{~A} 1$ & 0.3 & 100 \\
$\mathrm{Cl}$ & 1 & 1 \\
$\mathrm{Ca}$ & 1 & 10 \\
$\mathrm{TI}$ & 10 & 1 \\
$\mathrm{~V}$ & & 0.1 \\
$\mathrm{Mn}$ & 0.6 & 1 \\
$\mathrm{Cu}$ & 0.1 & 0.0003 \\
$\mathrm{Br}$ & & 0.0004 \\
In & 0.002 & 0.02 \\
I & & 0.5 \\
$\mathrm{Ba}$ & 2 & \\
\hline
\end{tabular}

A Above blank

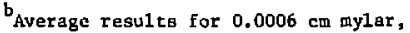
$0.0025 \mathrm{~cm}$ teflon, and $0.0025 \mathrm{~cm}$ polyechylene covered with $0.004 \mathrm{~cm}$ sticky resin.

A package of specialized Interactive programs is used to convert the raw gamma analygis data from G/MARAL, to elemental characterizations.

\section{Typical Output from Ingtrumental Neutron} Activation Analysis Sample

A typica! high volume air filter aerosol sample (IAS 21A) Is shown as an example of gamma apectra obtalned after ectivation. Figures $4-8$ are plots of the data for sample 21A resulting from the typical Irradiation and counting perioda described in Table 1. The Irradiation data Is shown for each spectrum presented, and Insofar as practicable, all peaks have been Identifled. Some of the peaks have not been Identified and labeled because their origin 19 not known. These unlabeled reaks may be peaks that can be attributed to more than one element, they may be single and double escape peaks, or they may be colncidence sum peaks.

SAMPLE PREPARATION AND HANDLING

Genera1

Sample preparation and handling are of greac lmportance in trace element work. Clean techniques must be observed at every step prior to Irradiation. After the sample is activated, the degree of care can be relaxed since the sample is eastly differentiated from any contaminarton, other than radfoactive, which might be introduced. The Insensitivity to handling procedures after Irradiation is one of the most attractive features of activation analyois. In order to maximize this advantage, preirradietion handing should be held to a mintrum.

If posstble, the sample should be transferred fron 1ts Irradlation contalner into a counting container, as this will elfinate the problem of subtracting the tracemelement rontent of the Irradiation container. If the sample is to be counted In Ita irradiation contalner or with a binder, the tracemalement content wust be well known from previous analyseg of a statistically significant number of containers or epecimens of binder. The same clean handling techniquea wutt be applled to the container or binder. 


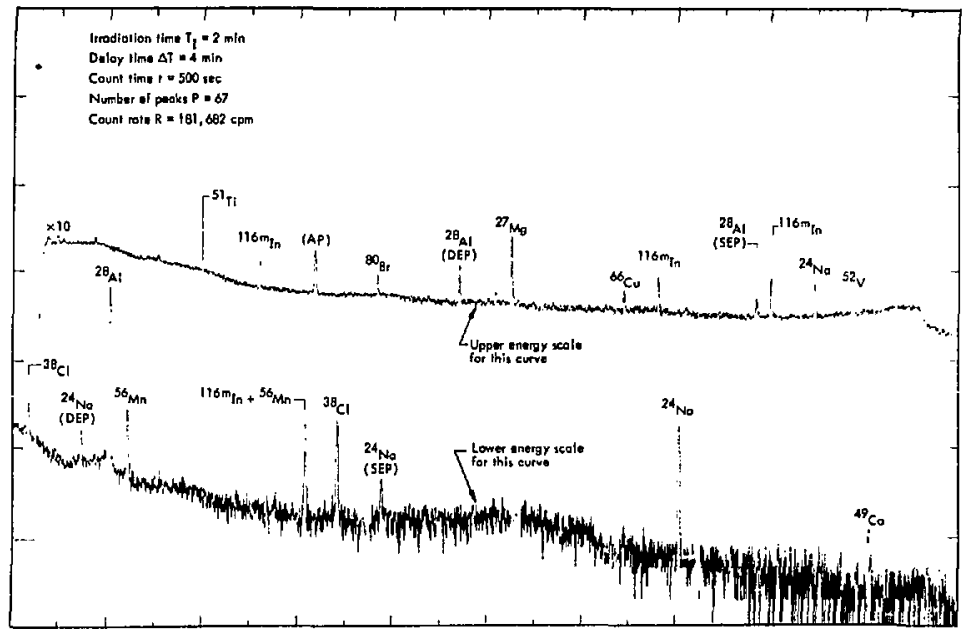

F1g, 4 INAA spectrum Q1 for high-volume air f1lter sample LAS-21A. Sample data: total alrflow through filter $958 \mathrm{~m}^{3}$; rass laading of alr as Indicated by material trapped in filter, $226 \mu \mathrm{g} / \mathrm{m}^{3}$. SEP - single eacape peak; DEP = double escape peak; AP - anaihilation peak.

Samples may be either in golld or 1iguid form, the solid being preferred. In general, liquid samples may require a concentration step before 1rradiation, In the case of 11 quide such as wilk, the anmple is brought to a solid form by freeze-irying.

\section{Sample Geometry}

The question of geometry must be considered in two aspect, Irradiation and counting. In some cases, the same geometry wil apply to both altuatione, namaly when tite disk ahepe, which in ideal for counting, can be 1rradiated. When the ouple sannot be irradiated id disk form, 1t any be poseible to approximate such a
Techniques have been worked out for preparing most dry samples in the disk shape for Irradiation. The basis of these techniques is the use of a hydraulic press and appropriate dies. Some samples, such as freeze-dried akin milk, will maintain their shape after pressing while others require the addition of some b1nder mater1al. If a binder 1s used, it must be treated as any other trace-clement content Introduced Into the sample.

In all cases, whether the sample $1 \mathrm{p}$ In a forw for coubting or not, each sample 1. accompanied by a flux monitor foll geometry during counting by packaging a poudered anple in a flat polyethylene envelope, or a liquid in a cylindrical vial. 


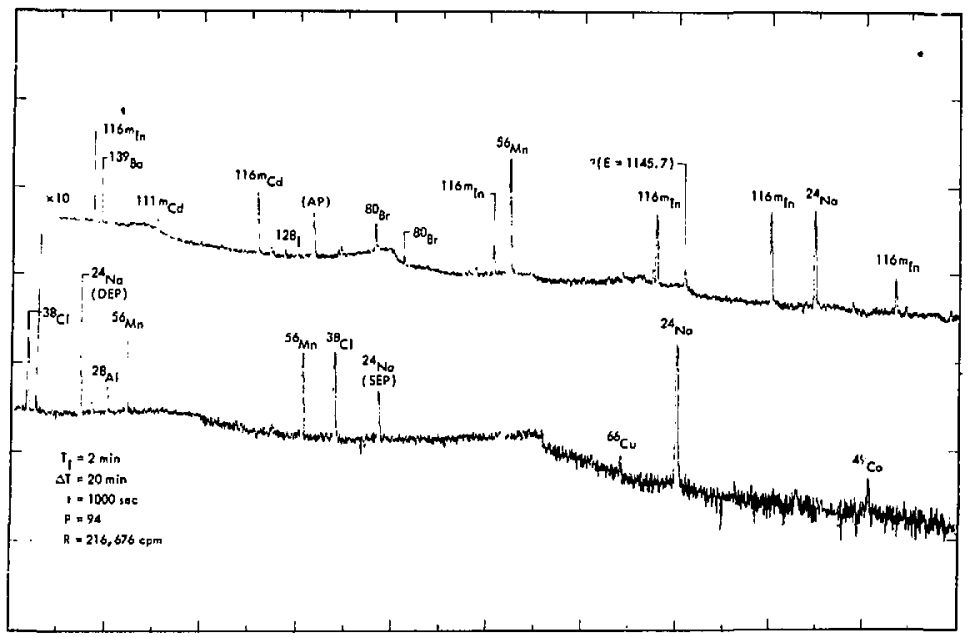

Fig. 5 INAA spectrum Q2 for high-volume air filter sample IAS-21A. (Sample data and abbreviations ane as Fig. 4.)

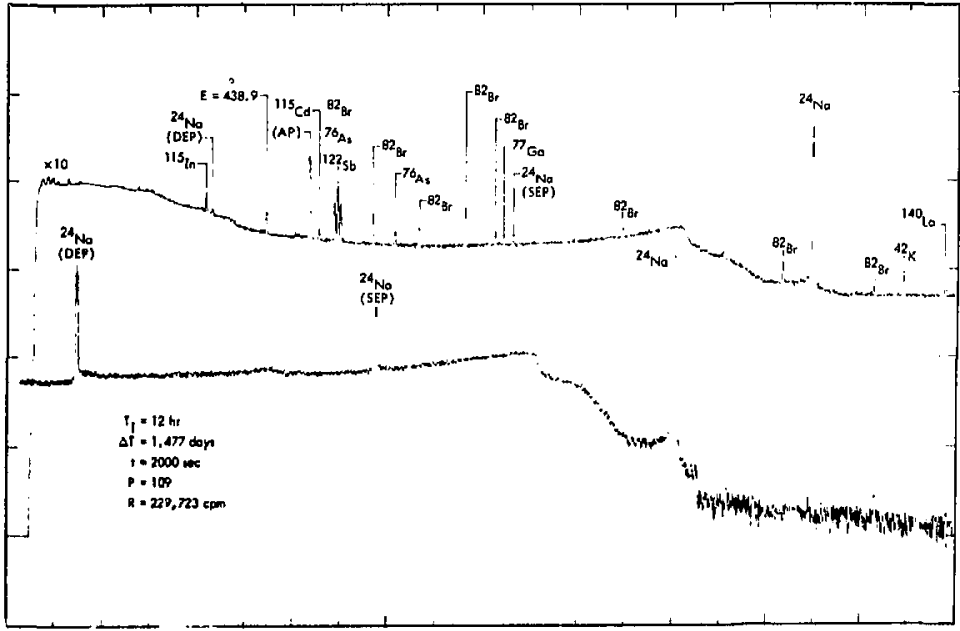

Fig. 6 INhs \& gecrum Ll for high-volume air filter agmple IAS-21A. (Sample data and abbraviatione ane ae Fig, 4.) 


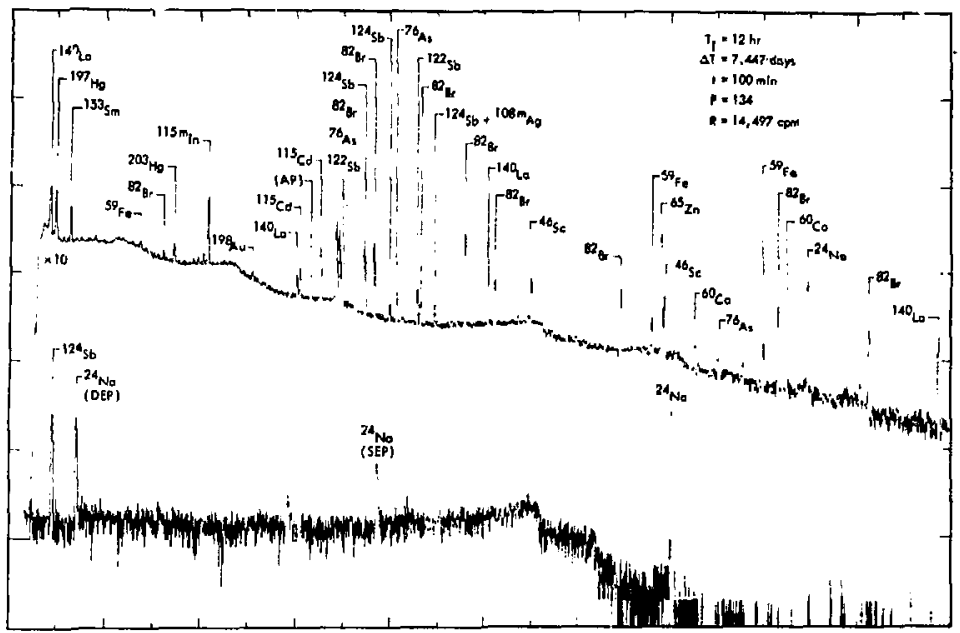

E1g. 7 INAA spectrum $L 2$ for high-volume air filter sample IAS-21A. (Sample data and abbreviacions same as $\mathrm{Fig} .4$.)

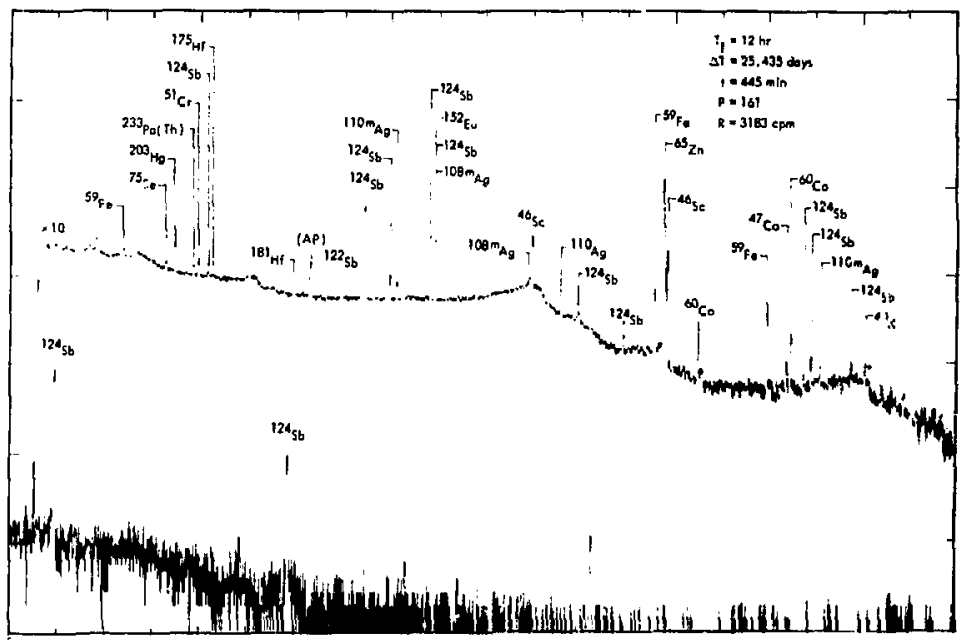

F1g. 8 INiAA opectrum 23 for high-volume alr filter sample LAS-21A. (Sample data and abbreviations came as Fig. 4.) 
during irrediation. Each foll is counted separately and emables ut to normalize for flux variations between samples and standerds.

\section{Liquid Samples}

When sample must be Irradiated in 11quid form, several precautiong must be obaerred. Babically the problem la that of leakage of the eample from 1 ts contatner. It can be asgumed that there will be $a$ bulld-up of pressure due to heating and radiolyais. It to neceasary to provide some space in the container for such a release of 8ag. About one-half to twothirds of the volume of the containet ghould be avallable for expanaton. The sample wust be gesled in ita container by welding, in the case of plaotic vials, or heat sealing for quartz. The heat-aenled prinary container must than be contalned In a leak-proof outer conteiner. The LPTP. ueer guide" provides phyatcal dinenalone of nott available outer contelnera.

After 1rradiation, the container it opened, and the l1quid 1e cransferred to a counting viel. It is poestble to count the asple in the irradiation container if counting geonetry and contalner blank are taken Into consideration.

\section{Solid Samples}

Solid saples hre a number of adventeges over 11quid, The nost important of these it the abence of leakats consideraction and the conequent relaxition of anding requiteants. These amples

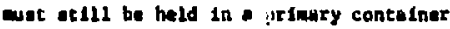
which se cloend tithely, but not neceerer$11 y$ sealed. There wat be a weondary container as in the cate of 1lquide.
Another advantage is the case of handling and the consequent reduction of axposure of personnel to radiation. Ag otated before, the oolid aample may be pressed into a dials ahape. The diaks are made in a varlety of diametera, ranging from a quarter-inch to one inch. If binder Is necessery, a weighed quantity la added to the welghed sanple. Powdered palyethylene and Avicel are two commerclally used binders. The polyethylene requires hesting to form the wafer and does not require nuch pressure. The Avicel requires no heat, but more pressure. Both materials have acceptable blanks for moat samples. Anong ooldd saaples we must include sarplea of suspended particles in air or other gases. Such particles are generally collected on the collection medta. The blank for the collection medis mugt be determined as for other casea.

Sample 51ze

The alzes of gamples varies with the type of sample, the matrix, and the inforantion dasired. Experimental conditions often deterwine sample Bize. For example, afe eapling Is 1 imlted by low concentrations of aerogol, gampling time, and collection aedin capacity. In other cases, enough eanle wight be avallable to produce any stze deatred, such as wth milk, con1, os 1 , atc. The lititing factora are then the awount of radtacion from the enjor constlifenta which can be handled and counted, and the mixture of ajor and crace alemente.

The range of eaple atzes uted in analyzing coat sollde is from $1.0 \mathrm{mg} \mathrm{cm}$ 1.0 8. Liquida cen be handled in awouncs up to about $30 \mathrm{nl}$. 


\section{Validation}

For the determination of the overall azcuracy of the use of INAA, we have access to three differenc cypes of ver:fications. The first of these verificationa 1 to to analyze some standard material and compare our measured values to those certifled by the agency lasuing the standard. In our case, we analyze orchard leaves as cert1fled by the Nationel Bureau of Standards.

The second approach is to particlpate In an Interlaboratory conparison of trace element determtations on various standardized samples. This was done for coal dust and fly ash in one serles, and for gravimetric standard solutions in another. Funally, and perhaps of zajor interest. is the possibility of intercomparison within an experimental program. This involves J direct comparison of the elements determined to be in the same sample by different analytical techniques, and a comparison of an uverall vlew of data produced by different techniques, not necessarily looking at the same elements.

N.SS ORCHARD LEAVES

Samptes of NBS atandard reference moterial - orchard leaves (SRM-1572) have been analyzed. The values ahown in Table 6 are averages of three to five replicates. The AuS certified values are also given. The values in parentheses are for Informational value only and are not certified. The experimental errors are equal to two atendard deviationa, or one-half the 1 ange of the data, whichever 1. preater.
Table 6. National Bureau of Standardo SRM-1571 Orchard leaves

$$
\left(\mu_{g} / g\right)
$$

\begin{tabular}{|c|c|c|}
\hline & LLL & InS \\
\hline Al & $341 \pm 39$ & $(350)$ \\
\hline $\mathrm{Ca}$ & $20400=1000$ & $20900 \pm 300$ \\
\hline $\mathrm{Ba}$ & $42.7 \pm 4.7$ & \\
\hline $\mathbf{M g}$ & $6600 \pm 500$ & $6200 \pm 200$ \\
\hline 85 & $13.0 \pm 2.6$ & (10) \\
\hline$v$ & $0.675 \pm 0.029$ & \\
\hline $\ln$ & $0.17 \pm 0.05$ & \\
\hline $\mathrm{Na}$ & $89 \pm 9$ & $82 \pm 6$ \\
\hline $\mathrm{Fe}$ & $330 \pm 40$ & $300 \pm 20$ \\
\hline cl & $635 \pm 47$ & $(700)$ \\
\hline $\mathrm{Mn}$ & $95 \pm 3$ & $91 \pm 4$ \\
\hline$A B$ & $8.8 \pm 3.4$ & $14 \pm 2$ \\
\hline $\mathbf{K}$ & $12200 \pm 3600$ & $14700 \pm 300$ \\
\hline
\end{tabular}

EPA-NBS INTERCOMPARISON SAMPLES OF COAL DUST AND FLY ASH

$$
\text { A "round-robin" Interconparisop }
$$

study was sponsored joincly by the National Burteau of Standards and the Environmental Protection Agency, The proposed standards were conl (SRM-1632), fly ash (SRM-1633), ganoline, and fuel oll. LLL participaced in the measurements of coal dust and fly ash,

Tables 7 and 8 show the reported resulta." 
Tabla 7. NBS-EPA fly ash (SRM-1633) comparison

$\mu_{g} / \mathrm{B}$ (unless indicated)

\begin{tabular}{|c|c|c|c|c|c|c|c|c|c|}
\hline & U. & of Md. & $\mathrm{NBS}^{\mathrm{a}}$ & & $\begin{array}{l}\text { thelle } \\
\text { N.W. }\end{array}$ & LIve & knore & $\begin{array}{l}\text { Washington } \\
\text { State }\end{array}$ & Oak R1dge \\
\hline $\mathrm{Na}$ & 0.342 & $\pm 0.03 \%$ & & $0.37 \%$ & $\pm 0.02 \%$ & $0.28 \%$ & $\pm 0.02 \%$ & & $0.34 \%$ \\
\hline $\mathbf{K}$ & & & & & & $1.38 \%$ & $\pm 0.06 \%$ & & $2.54 \pi$ \\
\hline $\mathrm{Ca}$ & $4.2 \%$ & $\pm 0.5 \%$ & & & & $4.48 \%$ & $\pm 0.26 \%$ & & 2.947 \\
\hline $\mathrm{Ba}$ & $0.27 \%$ & $\pm 0.03 \%$ & & 0.34 & \pm 0.04 & $0.26 \%$ & $\pm 0.02 \%$ & & 0.2762 \\
\hline Al & $15.8 \%$ & $\pm 1.2 \%$ & & $12.6 \%$ & $\pm 0.4 \%$ & $12.3 \%$ & $\pm 0.6 \%$ & & $8.74 \pi$ \\
\hline Se & & \pm 1.5 & & 27 & \pm 1.0 & 28.0 & \pm 1.7 & & 35.1 \\
\hline$T \dot{i}$ & $0,73 \%$ & $\pm 0.04 \%$ & & 0.76 & \pm 0.0 & 0.72 & $\pm 0.0 T$ & & 0.5888 \\
\hline$v$ & 251 & \pm 26 & $214 \pm 8$ & 220 & \pm 15 & 244 & \pm 24 & $223.6 \pm 12.3$ & 170 \\
\hline $\mathrm{Cr}$ & 130 & \pm 5 & $132 \pm 5$ & 131 & \pm 8 & 126 & \pm 10 & $126.2 \pm 4.3$ & \\
\hline Ph & 509 & \pm 15 & $495 \pm 30$ & 489 & \pm 11 & 506 & \pm 23 & $480 \pm 10.1$ & 441 \\
\hline $\mathrm{Fe}$ & $6.2 \%$ & $\pm 0.3 \%$ & & $6.51 \%$ & $\pm 0.31 \%$ & $5.8 \%$ & $\pm 0.3 \%$ & & \\
\hline Co & 41.2 & \pm 1.0 & 386 & 40 & \pm 2 & 42 & \pm 1.9 & & \\
\hline As & 59.6 & \pm 1.0 & $61 \pm 3$ & & & 51.7 & \pm 3.3 & $78.7 \pm$ & \\
\hline Sb & 7.8 & \pm 1.5 & & 7.2 & \pm 0.8 & 6.38 & \pm 0.41 & & $7.84 \pm$ \\
\hline In & & & & & & 0.32 & \pm 0.10 & & \\
\hline Hf & 7.9 & \pm 0.6 & & 8.2 & \pm 0.8 & 5.79 & \pm 0.38 & & \\
\hline $\mathrm{Ta}$ & 1.64 & \pm 0.12 & & 3.5 & \pm 0.3 & & & & \\
\hline$H$ & & & & & & 3.5 & \pm 1.1 & & \\
\hline La & & \pm 5 & & 82 & \pm 4 & 65.0 & \pm 6.6 & & B2.1 \\
\hline $\mathrm{Ce}$ & 156 & \pm 12 & & & & 135 & \pm 7 & & \\
\hline St & 13.8 & \pm 0.5 & & 12.4 & \pm 0.5 & 11.1 & \pm 0.7 & & \\
\hline Eu & 2.9 & \pm 0.2 & & 2.3 & \pm 0.1 & 2.22 & \pm 0.20 & & \\
\hline Th & 23.5 & \pm 2.0 & $24 b$ & 26.2 & \pm 1.3 & 23.3 & \pm 1.3 & & \\
\hline
\end{tabular}

Arobable certifled value, unless otherwise indicaced.

binformat lonal value only. 
Tabje 8. NBS-EPA COB: (SRH-1632) comparison

$\mathrm{Hg} / \mathrm{g}$ (unlese indfceted)

\begin{tabular}{|c|c|c|c|c|c|c|c|c|c|}
\hline & \multicolumn{2}{|c|}{ U. of Md. } & \multirow[t]{2}{*}{ NBS $^{a}$} & \multicolumn{2}{|c|}{$\begin{array}{c}\text { Battelle } \\
\text { N.W. }\end{array}$} & \multicolumn{2}{|c|}{ Livermore } & \multirow[t]{2}{*}{$\begin{array}{l}\text { Wasbingtor } \\
\text { State }\end{array}$} & \multirow{2}{*}{ Oak R1dge } \\
\hline $\mathrm{Na}$ & 339 & \pm 20 & & 420 & \pm 30 & 313 & \pm 22 & & \\
\hline K & & & & & & 0.23 & \pm 0.01 & & 0.3857 \\
\hline $\mathrm{Ca}$ & $0.41 \%$ & $\pm 0.05 \%$ & & & & $0.42 \%$ & $\pm 0.07 \%$ & & $0.268 \%$ \\
\hline $\mathrm{Ba}$ & 330 & \pm 30 & & & & 327 & \pm 19 & & 317 \\
\hline C1 & 970 & \pm 110 & & 800 & \pm 200 & 758 & \pm 62 & & 652.6 \\
\hline$B r$ & & -20 & & & & 18.6 & \pm 2.4 & & 16.0 \\
\hline AI & $1.78 \pi$ & $\pm 0.16 \%$ & & $1.78 \%$ & $\pm 0.08 \%$ & $2.0 \%$ & $\pm 0.1 \pi$ & & $1.23 \pi$ \\
\hline Sc & 3.70 & \pm 0.25 & & 3.4 & \pm 0.3 & 3.94 & \pm 0.19 & & 6.06 \\
\hline TI & 960 & \pm 100 & & 1110 & \pm 200 & 1060 & \pm 120 & & 789 \\
\hline v & 37.0 & \pm 3.3 & $35 \pm 4$ & 33.0 & \pm 4 & 38.3 & \pm 3.3 & $36 \pm 3.8$ & 26.4 \\
\hline $\mathrm{Cr}_{\mathrm{r}}$ & 19.7 & \pm 1.0 & $22 \pm 2$ & 19 & \pm 2 & 19.3 & \pm 0.97 & $21.25 \pm 0.43$ & \\
\hline Mn & 45.2 & \pm 3.2 & $47 \pm 3$ & 41 & \pm 6 & 47.6 & \pm 3.4 & & 38.6 \\
\hline Fe & $0.86 \%$ & $\pm 0.06 z$ & $0.80 \sigma^{b}$ & 0.827 & $\pm 0.07 \%$ & 0.817 & $\pm 0.04 \pi$ & & \\
\hline Co & 5.6 & \pm 0.3 & & 5.2 & \pm 0.4 & 6.04 & \pm 0.28 & & \\
\hline $\mathbf{2 n}$ & & -30 & & & \pm 4 & & & & \\
\hline $\mathbf{A s}$ & 5.7 & \pm 0.5 & $5.9 \pm 0.4$ & & & 5.04 & \pm 0.66 & $11.23 \pm 0.33$ & \\
\hline sb & 4,3 & \pm 3.0 & & 3.7 & \pm 2.0 & 4.1 & \pm 5.3 & & 4.4 \\
\hline In & & & & & & 0.20 & \pm 0.12 & & \\
\hline Hf & 0.95 & \pm 0.08 & & 0.97 & $\pm 0 . i$ & 0.72 & \pm 0.06 & & \\
\hline$W$ & & & & & & 0.62 & \pm 0.27 & & \\
\hline La & 11.3 & \pm 0.6 & & 10.5 & \pm 0.5 & 9.1 & \pm 0.38 & & 12.8 \\
\hline Ce & 20.4 & \pm 1.5 & & & & 98.5 & \pm 0.65 & & \\
\hline $5 \pi$ & 1.83 & \pm 0.09 & & 1.7 & \pm 0.3 & 1.43 & \pm 0.07 & & \\
\hline Eu & 0.38 & \pm 0.03 & & 0.28 & \pm 0.0 & 0.32 & \pm 0.03 & & \\
\hline Th & 3.0 & \pm 0.3 & $\mathbf{3}^{\mathbf{b}}$ & 3.45 & \pm 0.18 & 2.97 & \pm 0.17 & & \\
\hline U & & & & & & & & & 1.26 \\
\hline
\end{tabular}

"Prabable certifled value, unless otherwise indicaced.

bInformational value only. 
IKTERLABORATORY COAPARISON OF STANDARD SAMPLISS

A comparison of trace element concentrations detarmined by 5 different nondiapersive $x-r a y$ fluorescence techniques used at 11 different laboratoriea was recent Iy carried out. ${ }^{9}$ standard anples were prepaned by Columbia Scientific Industries. The INAA program at $L L L$ and the radioactive sourceexclted, nondisperaive $x$-ray fluorescence technique used at iLL were 1ncluded. our reeults compered with those reported by other Investigators, are ghown in line four of Table 9 .

Bach set of data reported In Table 9 was from our dried solution deposits and two blanks. The fllter oubst:ates were
Whatman 41" and Millipore SMTP filters. The elght elements deposites on each sample were $A 1, K, V, M n, F e, C u, A g$, and $P b$ in amounts ranging from $1.7 \mu \mathrm{g} / \mathrm{cm}^{2}$ to $54 \mu \mathrm{H} /$ $\mathrm{cm}^{2}$. AII investigators recelved separate betg of gtandards. ILL uaed the aare set for x-ray analyele prior to INAA.

The gravimetrie standard solutions deposited on Whatman 41 are referred to as " $A$ " and " $C$ ". The values shown for each element in Table 9 are ratios of the hatman 41 and M1111pore filter averages to the amount of gravimetrits gtandard oolution deposited. Each participant knew only which elements were depostted, not how much. The numbers in parentheses are the standard deviations reported by the various participants.

*Reference to a company or froduct name does not imply approval or recomendation of the product by the Univeraity of California or the U.S. Energy Research \& Development Adninistration to the exclugion of othere that may be sutcable.

\section{Applications}

TRACE ELEDETS IN AEROSOLS

\section{The Callfornis Aoroeal Charecterization Experimant (ACHEX) 1972-1974}

Socte of the moce pressing questions of air pollution requiring inproved knowledge ere those ivining with aecosole. Although alrborne partioles represent a rial1 fraction of the trace conetituent looding in air, they contrilute aignfficantly to onvironesent degradation as a pocenciel hezard to health, a vialbilfty reducer, and a possible agent of weather modification. Deepite many years of $\mathbf{I n}^{\mathrm{n}}$ veatigation, the origing and evolution of atmo:Jphtic aerosole remain poorly underatood quantitatively, compared with trace genes. Recognizing this, the Callfornia A1r Resourcea Bosid (ARB) sponsored a maJor experiment in air chemiatry, devoted to a detalled study of aerosole In urban and renote aftes of Callfornia. ${ }^{2}$

As the objectives note, the project was oet up in Buch a way as to emphasize 
Table 9. First XRF intercomparison study

Rat lo of A anc C averages to gravinetric standards

\begin{tabular}{|c|c|c|c|c|c|c|c|c|c|}
\hline $\begin{array}{l}\text { Set } \\
\text { no. }\end{array}$ & $\begin{array}{c}\text { Sample } \\
\text { type }\end{array}$ & Al & $\mathbf{K}$ & $y$ & Mn & $\mathrm{Fe}$ & $\mathrm{Cu}$ & As & $\mathrm{Pb}$ \\
\hline 1 & $\begin{array}{l}\mathrm{A} \\
\mathrm{C}\end{array}$ & & $\begin{array}{l}0.09(.21) \\
0.73(.24)\end{array}$ & $\begin{array}{l}0.76(.06) \\
0.68(.10)\end{array}$ & $\begin{array}{l}0.64(-06) \\
0.68(.08)\end{array}$ & $\begin{array}{l}0.57(.20) \\
0.65(.10)\end{array}$ & $\begin{array}{l}0.53(.08) \\
0.60(.10)\end{array}$ & $\begin{array}{l}0.48(.07) \\
0.69(.08)\end{array}$ & $\begin{array}{l}0.57(.07) \\
0.74(.09)\end{array}$ \\
\hline 2 & $\begin{array}{l}A \\
C\end{array}$ & 1.73 & $\begin{array}{l}0.67 \\
0.91\end{array}$ & $\begin{array}{l}0.72 \\
0.77\end{array}$ & $\begin{array}{l}0.76 \\
0.83\end{array}$ & $\begin{array}{l}0.67 \\
0.74\end{array}$ & $\begin{array}{l}0.79 \\
0.76\end{array}$ & $\begin{array}{l}0.61 \\
0.63\end{array}$ & $\begin{array}{l}0.69 \\
0.69\end{array}$ \\
\hline 3 & $\begin{array}{l}A \\
C\end{array}$ & & $\begin{array}{l}0.92(.07) \\
0.91(.06)\end{array}$ & $\begin{array}{l}0.91(.07) \\
0.90(.06)\end{array}$ & $\begin{array}{l}0.95(.07) \\
0.92(.04)\end{array}$ & $\begin{array}{l}0.91(.03) \\
0.89(.04)\end{array}$ & $\begin{array}{l}0.92(.04) \\
0.91(.03)\end{array}$ & $\begin{array}{l}0.90(.04) \\
0.89(.03)\end{array}$ & $\begin{array}{l}0.94(.03) \\
0.88(.03)\end{array}$ \\
\hline $\begin{array}{l}\text { LLL } \\
\text { INAA }\end{array}$ & $\begin{array}{l}A \\
C\end{array}$ & $\begin{array}{l}0.79(.01) \\
0.79(.08)\end{array}$ & & $\begin{array}{l}0.91(.01) \\
0.89(.01)\end{array}$ & $\begin{array}{l}0.94(.02) \\
0.96(.02)\end{array}$ & $\begin{array}{l}0.84(.01) \\
0.83(.02)\end{array}$ & $\begin{array}{l}0.89(.19) \\
1.20(.19)\end{array}$ & & \\
\hline 5 & $\begin{array}{l}A \\
C\end{array}$ & & $\begin{array}{l}0.02(.02) \\
0.81(.03)\end{array}$ & $\begin{array}{l}1.01(.02) \\
0.97(.03)\end{array}$ & $\begin{array}{l}0.99(.03) \\
0.95(.03)\end{array}$ & $\begin{array}{l}0.92(.02) \\
0.91(.03)\end{array}$ & $\begin{array}{l}1.00(.03) \\
0.96(.03)\end{array}$ & $\begin{array}{l}0.94(.03) \\
0.94(.03)\end{array}$ & $\begin{array}{l}1.05(.03) \\
0.99(.03)\end{array}$ \\
\hline 6 & $\hat{C}$ & $\begin{array}{l}1.55(.20) \\
2.51(.37)\end{array}$ & $\begin{array}{l}0.94(.01) \\
1.01(.01)\end{array}$ & $\begin{array}{l}0.92(.01) \\
1.64(.01)\end{array}$ & $\begin{array}{l}1.01(.02) \\
0.95(.02)\end{array}$ & $\begin{array}{l}1.01(.01) \\
0.96(.01)\end{array}$ & $\begin{array}{l}0.91(.03) \\
0.88(.02)\end{array}$ & $\begin{array}{l}0.76(.07) \\
1.20(.08)\end{array}$ & $\begin{array}{l}0.98(.05) \\
0.92(.03)\end{array}$ \\
\hline 7 & $\begin{array}{l}A \\
C\end{array}$ & $\begin{array}{l}1.36(.12) \\
1.78(.11)\end{array}$ & $\begin{array}{l}0.95(.06) \\
1.15(.07)\end{array}$ & $\begin{array}{l}0.90(.06) \\
1.12(.08)\end{array}$ & $\begin{array}{l}1.10(.07) \\
1.17(.08)\end{array}$ & $\begin{array}{l}1.00(.05) \\
1.06(.04)\end{array}$ & $\begin{array}{l}0.92(.04) \\
1.07(.06)\end{array}$ & $\begin{array}{l}0.86(.06) \\
0.88(.05)\end{array}$ & $\begin{array}{l}1.00(.05) \\
1.01(.05)\end{array}$ \\
\hline 8 & $\begin{array}{l}A \\
C\end{array}$ & & $\begin{array}{l}1.06(.16) \\
1.03(.15)\end{array}$ & $\begin{array}{l}1.01(.15) \\
1.07(.16)\end{array}$ & $\begin{array}{l}1.12(.17) \\
1.02(.15)\end{array}$ & $\begin{array}{l}1.11(.17) \\
1.09(.16)\end{array}$ & $\begin{array}{l}0.97(.16) \\
1.11(.17)\end{array}$ & $\begin{array}{l}1.03(.15) \\
1.15(.17)\end{array}$ & $\begin{array}{l}0.96(.15) \\
1.06(.16)\end{array}$ \\
\hline 9 & $\begin{array}{l}A \\
C\end{array}$ & & & $\begin{array}{l}0.86 \\
1.04\end{array}$ & $\begin{array}{l}0.90 \\
1.10\end{array}$ & $\begin{array}{l}0.98 \\
1.16\end{array}$ & $\begin{array}{l}1.0 ! \\
1.17\end{array}$ & $\begin{array}{l}i .00 \\
1.11\end{array}$ & 1.03 \\
\hline 10 & $\begin{array}{l}\text { A } \\
C\end{array}$ & $\begin{array}{l}1.66(.25) \\
1.76(.26)\end{array}$ & $\begin{array}{l}1.28(.18) \\
1.25(.20)\end{array}$ & $\begin{array}{l}1.15(.17) \\
0.91(.14)\end{array}$ & $\begin{array}{l}1.21(.19) \\
1.11(.18)\end{array}$ & $\begin{array}{l}.93(.13) \\
.84(.12)\end{array}$ & $\begin{array}{l}.74(.23) \\
.86(.10)\end{array}$ & $\begin{array}{l}1.10(.25) \\
1.05(.24)\end{array}$ & $\begin{array}{l}1.13(.27) \\
1.09(.24)\end{array}$ \\
\hline 11 & $\begin{array}{l}A \\
C\end{array}$ & $\begin{array}{l}0.71 \\
0.58\end{array}$ & $\begin{array}{l}0.92(.06) \\
0.92(.06)\end{array}$ & $\begin{array}{l}1.10(.06) \\
1.17(.09)\end{array}$ & $\begin{array}{l}1.03(.08) \\
1.09(.08)\end{array}$ & $\begin{array}{l}1.01(.08) \\
1.09(.08)\end{array}$ & $\begin{array}{l}0.88(.09) \\
0.92(.07)\end{array}$ & $\begin{array}{l}0.93(.12) \\
1.06(.17)\end{array}$ & $\begin{array}{l}0.84(.08) \\
0.81(.09)\end{array}$ \\
\hline 12 & $\begin{array}{l}\Lambda \\
C\end{array}$ & $\begin{array}{l}6.5(2.1) \\
5.0(1.3)\end{array}$ & $\begin{array}{l}1.13(.18) \\
1.18(.15)\end{array}$ & $\begin{array}{l}0.99(.07) \\
1.02(.10)\end{array}$ & $\begin{array}{l}1.01(.09) \\
1.06(.12)\end{array}$ & $\begin{array}{l}1.01(.11) \\
1.11(.12)\end{array}$ & $\begin{array}{l}1.01(.12) \\
1.04(.10)\end{array}$ & $\begin{array}{l}1.08(.15) \\
1.18(.16)\end{array}$ & $\begin{array}{l}1.04(.10) \\
1.07(.11)\end{array}$ \\
\hline
\end{tabular}


primary particle sources, atmoopheric formation, and their relation to changes In vistbility. In California, the "secondary" production of aerosols by chemical and physical processes in the atmosphere $1 \mathrm{a}$ belleved to be eapecially important.

The objectives of the study to which INAA were applied were:

1) To characterize the serosol in the South Coast, the San Franctaco Bay Area, and the San Joaquin Valley Basins, In terms of 1 ta Interaction in the atmosphere, and Its natural and anthropogente origins.

2) To evatuate the mount of the atmospheric aerosol to the cited three major atr basins which can be related to: (a) primary emisstons, such as from auto exhausts or amokestacke, and (b) Becondary production, due to physical and chemlcal processes taking place In the atmosphere.

3) To Identify those major sources of particles which can be related to aerosol pollution and visibility reduction.

4) To evaluate the applicability of the aerosol analysis 1ngtrumentation employed in this study for use in present monttoring networks.

The results of the experiment revealed an extremely complicated behavior of atwophertc aerosola, as they are 1nfluenced by locel cources, Bas-particle Interaction, and aeteorological factore. However, certain Important common features of airborne particlea were found, For Instance, the ffort showed clearly that man's activities and atmospheric transformations of Baseous pollutants contribute primerily to the aubaicron particle alze range, while primary natural sources influence the range $>1$ 面 diameter.

Approximately 700 filter and impactor samples were analyzed during the atudy. Total aerosol specimens were collected on $5 \mathrm{~mm}$ celluloge acetate membrane $\mathrm{f} 1 \mathrm{I}$ ters using low-volume atr gamplerg. Multistage rotating drum cascade Impactore were used to collect size-segregated aerosols. The particle-size distributions obtained had $50 \%$ cut polnte of $8.0,4.0,1.5$, and $0.5 \mu \mathrm{m}$. Cellulose acetate after-f 11 ters collected particles >0.5 $\mathrm{jm}$.

The aerosol specimens were routinely analyzed for $\mathrm{Na}, \mathrm{Mg}, \mathrm{A} 1, \mathrm{Cl}, \mathrm{Ca}, \mathrm{T} 1, \mathrm{~V}$, $\mathrm{Mn}, \mathrm{Cu}, \mathrm{Br}, \mathrm{In}, \mathrm{I}$, and Ba using a 2-minute Irradiation at 3-legawatts in the LPTR followed by 9 and 20-minute counts (Table 1). Sensitivities obtained for 10 of the elements were routinely less than $10 \mathrm{ng} / \mathrm{cm}^{3}$. Selected samplea were further analyzed for $\mathrm{Eu}, \mathrm{Ce}, \mathrm{Se}, \mathrm{Th}, \mathrm{Cr}, \mathrm{Hf}, \mathrm{Ag}, \mathrm{N} 1, \mathrm{Sc}, \mathrm{Fe}$, an, and Co, using a 12-hour Irradiation followed by an 800-minute count after a 3-week tecay.

The ACHEX data on the diatribution of aerosol compogition with size confirm the hypothesis that constituents originating from certain classes of sources dominate the mase in particular alze ranges. Primary materlal from combustion, chemical, and metal refining sources eppear atrongly In the aubricron (or anthropogentc) fraction. Examples Included Br, C1, and 7 . In the oupermicron fraction appear the natural or quasinatural elements such as $\mathrm{Na}, \mathrm{Cl}, \mathrm{Al}, \mathrm{Fe}, \mathrm{Ca}$, and Sc. In this study the natural backsround nerosol consiated 
of a mixture of 6 ea salt, soll dust, and a residue of aged aerosol transported from distances away from an urban area.

Aluminum was found principelly in the larger particles (8-15 $\mu \mathrm{m})$ at all urban, inland, and coastal altes. Since large particles are usually a result of windblown soll erosion, the Al concentrations were used as Indicators of the amount of soll component in the gerosols. Other elements with Al-like distributions were $\mathrm{Ca}, \mathrm{Mg}, \mathrm{Mn}, \mathrm{Sc}, \mathrm{Th}, \mathrm{Fe}$, and $\mathrm{Co}$, Implying they were also soil-derived. The V diatrdbutions were bimodal with maxima at sutmicron ranges $(<0.5 \mu \mathrm{m})$ and large particle-alzes $(>8.0 \mu \mathrm{m})$. These data suggest two gources of $V$, soll dust and combustion (probably the burning of residual fuel all) processea.

The Na at cosetal sites was from seasalt and present in the $1.5 \sim 4.0 \mathrm{wm}$ particle size range. The $\mathrm{Na}$ at inland sites was derived from soil-erosion and found in the large-particle range, 8-15 $\mu \mathrm{m}$. At cosstal sites the Cl distribution followed the Na distribution. At inland sites the submicron $\mathrm{Cl}$ (as well as the $\mathrm{Br}$ ), which was due to automotive emissions, Increased significantly.

A secondery, but Important role of INAA, was the validation of other analycical techniques utilized in the chemical analysis of aerosols. Supplementel experiments were also performed using INAA to validate the collection efficiencles of rotating atage cascade impactors.

As a cesult of these studies, it was concluded that techniques using INAA were useful operational methode for chemical analysia of aerosol sanples taken over two-hour perfods in urban air in an active monitor Ing program. Theoe techniques have been sumerized in Ref, 10.

\section{Air Sampling in the Vicinity of Smelting Operations}

An example of what can be accomplished In aerosol characterization 18 shown by a study of air filter samples collected at Kellogg, Idato, ${ }^{1}$ in the Coeur d'alene mining district. Samples were analyzed to determit.e the concentrations of trace metallic elements in the air, and to look for indications of their gources. For example, aome elements are in the air as a result of the mining and smelting operat1ons, others are there "naturally" through belug picked up by the winde from the soil surfaces.

The samples were analyzed for 34 elements with Inatrumental neutron activation analysis, and for 6 elements with $x$-ray fluorescence analysis. The elemente observed ware divided Into three maln groups according to their earichment factors (defined as enrichment of the eloment concentration relative to the worldwide average concentration in the earth's crustal rock). The elements wh low enrichment factors $(<100)$, were considered to be derived primarily from the soll. Those with an interdediate enrichment factor (100 to 1000) are considered to be of uncertain origin (soil and/or mining and amelting). Those with a high enrichment factor $(>1000)$, are considered to be clearly of mining/smelting origin.

From a cursory examination of Figs. $9 a-9 g$ one may draw several conclusions as to the possible sources of some of the possible sources of some of the slements. 
From Fige. $9 a$ \& $b$ we can see that $P b, Z n$, $\mathrm{Cd}, \mathrm{In}$, and possibly $\mathrm{Ag}, \mathrm{Au}, \mathrm{Se}, \mathrm{Sb}$, and H8 have aimilar concentration patterns as \& function of time. However, they are not correlated with the behavior of the total mags of the sample. From Flgs. 9c \& d we see several elements that tend to have a distribution simflar to that of Al. I. Fig. 9e, 9t, \& $9 \mathrm{~g}$ we obaerve elements tib" do not appear to be very well related to either the $\mathrm{Pb}$ or A1 diatribution. From the observation of the daca in FIgs. 9a98 , one would conclude that the elements can be Brouped into three general classes:

(1) those with a pattern oimflar to that of lead, probably associated with the mining or smelting Indugtry; (2) those with a pattern oimllar to that of $A$ I and therefore probably relaced to the soll; and (3) those that do not seem to fall into elther of the first two classes.

The relationship between the results of XRPA and INAA is shown In F133. 10 for $\mathrm{Cu}, \mathrm{Br}, \mathrm{Fe}$, and $\mathrm{z}$. The solld line represents a correlation coefficient of 1.0 , or perfect correlation. The 11near correlation coefficlente of these four elemente are $0.98,0.96,0.93$, and 0.97 , respectively. for $\mathrm{Cu}, \mathrm{Br}, \mathrm{Fe}$, and $\mathrm{Zn}$. For these samplea a linear correlation coefficlent of 0.35 to the minimum value for correlation.

Soll and Vegetation Trace Metal Contaminathon Hear Zinc and Lead Smeltera

Soll cores and vegetation sampies were taken at 12 sites in the vicinity of $\mathrm{Zn}$ and $\mathrm{Pb}$ seelters In XellogB, Idaho. 1 Thirty-four elementa were analyzed using the techniques of Instrumental Neutron
Activation Analysis and x-ray fluorescence analysis. The soild and vegetation were found to be highly contamlneted with $\mathrm{Pb}$, 2a, Cd, As, Hg, Se, Sb, Ag, and In. These same elements had been found at high concentrations in amblent a." aeroso?. collected in Kellogg two miles from the smelters. In the surface soll fraction the concentrations were 170 to $7900 \mathrm{ppm}$ $\mathrm{Pb}, 220$ to $13000 \mathrm{ppm} \mathrm{zn}$, and 18 to $140 \mathrm{ppm}$ cd. In the vegetation the concentrationg were 220 to $10000 \mathrm{ppm} \mathrm{Pb}, 450$ to $12000 \mathrm{ppm}$ $\mathrm{Zn}$, and 16 to $950 \mathrm{ppm} \mathrm{Cd}$. The aerosol enrichmenc factors relative to the mean surface sol1 concentrations were 4100 for $\mathrm{Cd}, 180$ for $\mathrm{As}, 110$ for $\mathrm{Pb}$, and 60 for $\mathrm{Zn}$.

UPTARE OF TRACE METALS BY VEgETABLES GROWN IN LTVERHORE TREATHENT PLANT SLUDGE

The Laboratory routinely releases small quantities of trace elements and radionucildes into the Liverwore sewer system, in accordance with approprlate standards. At the Livermore Waste Water Treatment Plant these tend to separate with the digested sludge. Thls sludge is avallable to the public for use as a soll conditioner. A study ${ }^{3}$ was conducted at LLL during 1974 to deteruine the uptake of these elementa by edible crope grown in sol1 treated with aludge.

sludge was applied $7 \mathrm{~cm}$ thick to an experimental garden plot $10 \mathrm{~m}$ by $15 \mathrm{~m}$. So11 was mixed to $14 \mathrm{~cm}$ with a rototiller, giving a 50\% sludge mix. A control plot of similar dimensiona but with no added ool1 conditloner or fertilizer was aleo establiahed, A variety of plants and seeds were planted that would produce root, stem, 

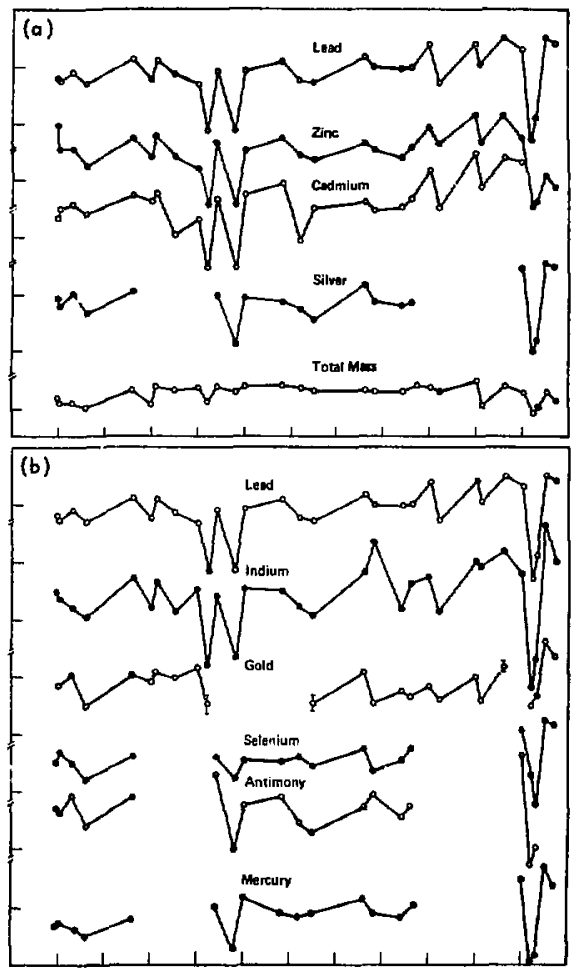

1g. 9a-g Concentration of various txace elements 1 in the alr as a function of sampling date, for aic ftlter samples taken In Kellogg, Idaho, 1972. 


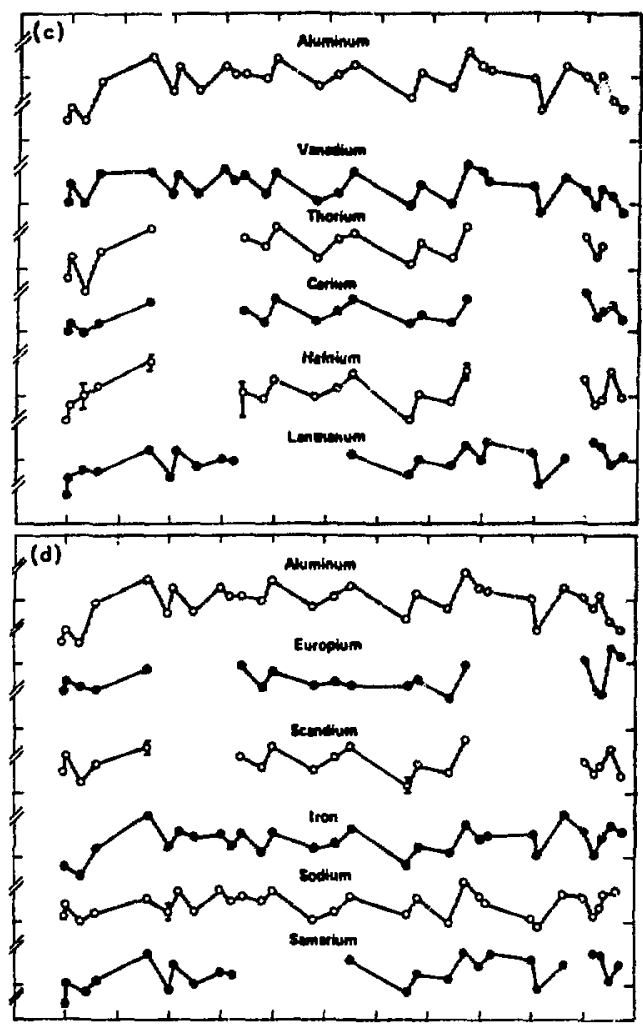



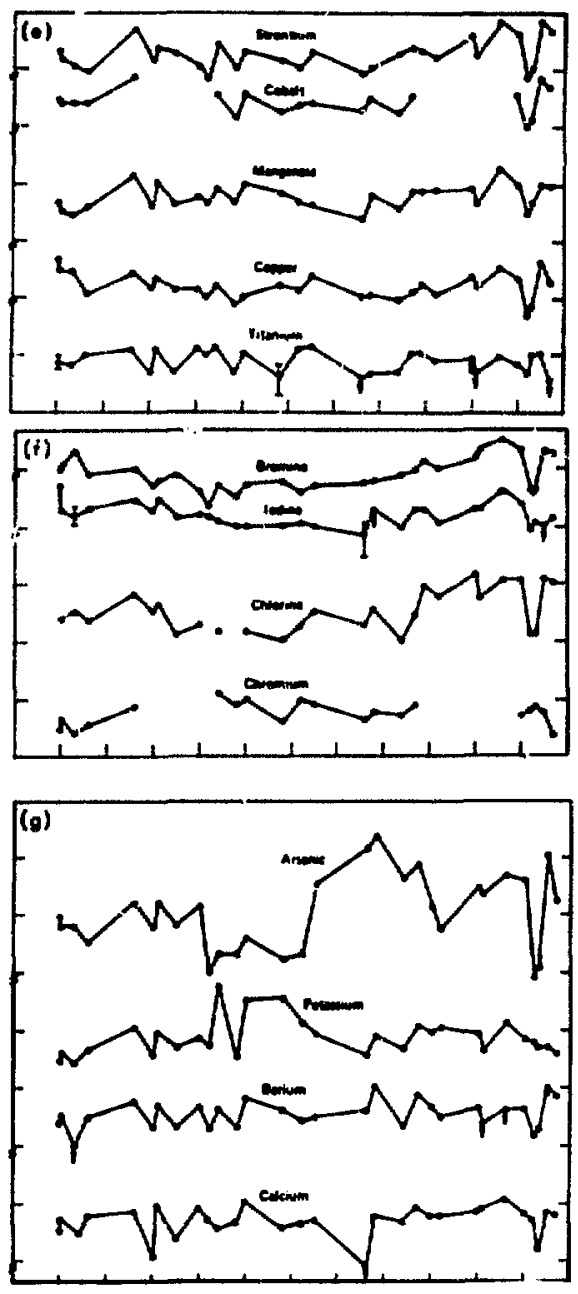

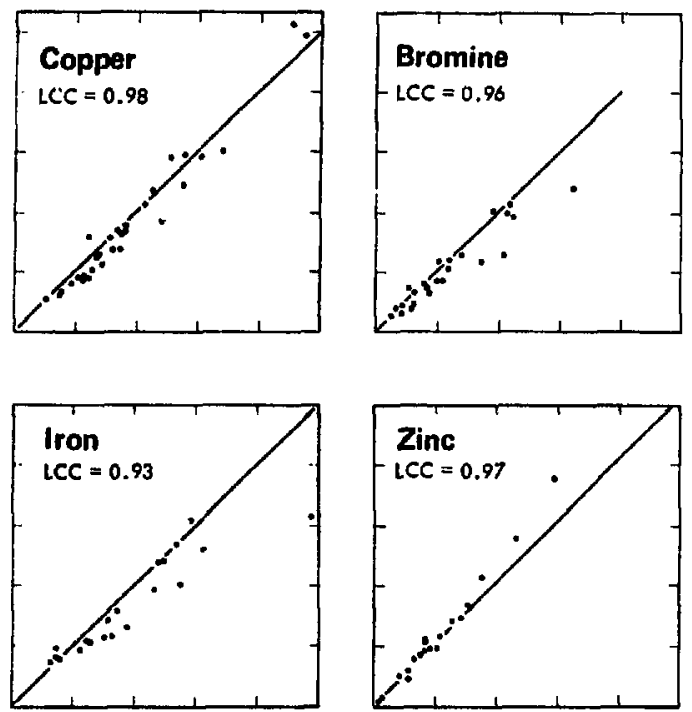

Fig, 10 Correlation of INA and XRFA results for $\mathrm{Cu}, \mathrm{Br}, \mathrm{Fe}$, and $\mathrm{Zn}$. Iinear correlation coefficient (LCC) values are shown: a value of 0.35 or higher indicates a positive correlation.

leaf, flower, fruit, and aeed parts that could be analyzed for upeake of the several elemente of Intereat.

Trace-elenent content vel deteralned principally by atonic absorption and neutron ectivation.

\section{Princtpal Findinge}

Zinc and cadatue luvel in the aludge 0011 vere 15 to 75 t1was higher than those In the control soll. Freezo-dried lettuce and radioh leaves from plance grown in aludge colle containod $\mathrm{Zn}$ and $\mathrm{Cd}$ levele equal to those in the soil. Although the Sn levele in the aludge coil and control so1l vere about equal, Sn uptake was much htgher in control-grown plancs than in those grown in the sludge garden. The $\mathrm{Ca}$ content of the aludge soll was higher than In the control, and the plante may have reached cheir capacity for divalent alkaline earth lons with Ca. Copper levels In the sludge soll were 20 times higher then in the contral ooll, but plants growa in the aludge soll ehoved no hygher $\mathrm{Cu}$ uptake. Chromiut uptake was also negligible. Finally, beeds showed very little concentration of trace elenents, while leaves generally were quite responsive to change in trace metal content of the ooll. 
IMAA OF MARINE SAMPLES DEVELOPED IN THE MARINE STUDIES PROGRAM

In coastal reglons, reactors located ou the coast can use gea water for cooling and for disposing of low level radloactive wastes. The Blomedical and Environmental Research Division had undertaken a coastal stodied program whose purgose wag to tauestigate the fate of radionuclides released into a marine environment. One phase of the program involved the study ${ }^{22}$ of the Pacific Cas and Electric Company reactor at Humbolt Bay, where over a three year perlod all reactor releases were assayed for radionuclide composition and concentration and the uptake of the radionuclides by sediments and biota was followed. Stable element concentrations in the varioug environmental compartmenta were determined by neutron activation analyois. We kant to know the concentration in each compartment of the stable element councerpart for each of the radiouclides released In order to under atand the observed radionuclide partitioning. Thus, if we know that In a particuler aqueous p.sol the ratio of radloactive ${ }^{65} \mathrm{Zn}$ to stable $\mathrm{Zn} 1 \mathrm{~s}$ $0.3 \mathrm{pC} 1 / \mu \mathrm{g}$; and $1 \mathrm{f}$ we know that mature oysters have stable $2 n$ concentrations of $4000 \mu \mathrm{zn} / \mathrm{kg}$ wet weight of oyster, then wo expect the concentration of radioactive ${ }^{65} \mathrm{Zn}$ in the oysters to reach $.3 \times 4000$ or 1200 pct/kg wet wisght.

Elements of Intereat in the conetal otudies program are those having a radioactive counterpart which is released into the marine environment. Since theae are all reletively long-lived epectes produced by neutron capture, the method of Instrunental keutron Activation Anilyoio for deterainting chane elewente is particu- larly appropr 1ate. Elemente required for the Hunbalt Bay study were Ce, Ce, $\mathrm{Hn}, \mathrm{Zn}_{\mathrm{n}}$ and $C_{0}$. These were determined for three anin catagories of samyle - seawater. sediment, and blota. Seawater samples were filtered and acidified at the point af collection. At the laboratory. the trace elements from four liter samples were preconcentrated, firat by evaportatson to reduce water volume by a factor of four, and gecond by selectively precipitating elements of interest to eliminate sodium which in seawater is a major Interference. The ashed precipttates were Irradiated for elght hours, cooled for one week, and counted to determine the quantity of the activacton products.

Sediment bamples were dried and then $100 \mathrm{mg}$ aliquots were irradiated, cooled. and counted using the same gchedule as above. Thts schedule was also followed for the biota samples. In this case, however, the original bialogical material was first drled and then ashed at $450^{\circ} \mathrm{C}$ to provide a $100 \mathrm{mg}$ sample.

In all cases, additional elements were routinely determined by the analysis. These Included Sc, U, Th, Cr, Nd, Mo, Fe, Sm, Ag, Rb, and Eu; although not every one of these elements was determined on every type of Bample.

FORENSIC ANALYSIS

An area currently being investigated 1. Foreneic analyals, There 18 an $1 n-$ creasing need to provide sclentific support to law enforcement sroups to aid in the resolution of crintnal cases. A very practical and valuable test 18 one for gunshot residue determinetion. The reaults of the teat indicate whether it is 
11kely that a supece hate flrad a gun. Th10 10 done by andyalne aulpe froe the suopace' a hands tor antiony and bariu traces. If the usupect tat firad a zun, traces of antiony and bertue w111 probably be deposited as residuse fron the dispersel of postler fros the bullet priwer.

Trace elesent analyaie can provide valuable Information in wny ocher saya. Hefr trace analyola can be unad for ladicecton of ereente polsoning. analyets of hait, paint, glowa, fibers, oil, rubber and afacellaneoun aterials can be used to connect a subject to a crise.

Another ltiportant area in Iaw enforcewent it the abilicy to tag 1tant wo that positive Identifict.:ion can be and at a later time. Sona applications are: togglag ltens to be sold by an undercover egent to a known fanca, or 1ntroduced into the chatn of a anggling oparation. Eventually an arrest is mads, aidd if the Iteas can be traced to the rource, it cen be valuable information for obtaining a conviction. He have tagged over 175 iteme for the U.S. Custona Service, and nome have been recovered and Identified. This inforation has ban used as mafor evidence in two felony court caess. 13

Conventional wethods, such as tageing with dyen that will ehow up under bleck itght, are becoming lene ef factive

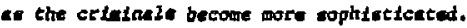
For that resson, ney tagsing mathods are required. Three mathode we have worked wth are: vacuum deposition of race arth elements, affixing uniquely-coded microspheres, and evaporstion of rare encth mixture wolution. Other methode under consideration are diffuaton and fon implantation. In all of chuse methode, known ratio of rare earth elements are af lixed in some ray to an object sueli as an teen of Jevelicy. If the Item Is lost at stolen and lacer recovered, the tag can be decec= cad and provide a positive aeuns of idene1fleation. Derection can be semaplished by Inutrumantal kestron Activation Analysie.

Thore are meny other usts for posicive Identifleation marking methods. Thef $t$ frop the docke and shipping loases are an ever increasticg problem. Ineurance conpanies and trade protective aeaciations as wall as law onforcenent agencles could ure and benefte frow auch poetrive identiftcation methods. With the developaent and applicaction of there techatques, a fance will no longer be able to buy stolen gands and feel secure that the item ta not identifiable as atolen property.

TRACE ELEMENTS IN MIL:

The role of trace elements in the enviroment both as toxic materials and as essential nutriente for planta, animals, and man is well recognized. However, except for a Eew notable examples, very litele information is evallable on the pregence and flux of these elements through the bioophery and into huan food chains. With the preacitly Incteading concern over energy-related trace element pollution, It becones mont appropriate to undertake - comprehensive study of trace elements in major food chaing by rodern instrumental methods of multi-elesentel analynis. This documentetion to of value both in iteelf and in Improving the underatanding of redionuclide behavior in the environment. 
The specific abjectives of the T.LL soll-forege-cow-allh food choln study are:

1. To document trace-elownt level. in each compartenent of this food chain to permit broed incerprezations of the relationship between trace elewents in allk, obsl chatacentincice, clinate, dalty angeant rractices, and Industriel pollution;

2. To evaluste the usefulness of alk as an indicator of traceelewent pollution in the envitonment ant ko establish baseline levels of sontamination;

3. To develop wethods and sodele for future sysematic Investigation: of ocher fbod chalne and other entariala.
Al1 trace elemante decketable by the oulcl-elemental analytianl techniques will be reported, but particular aphasis will be pleced upon thoue known or ouspected of being roxic or essential. The results w11l ba date-banked and evaluated for etariatically significant correlations.

The resules of the firat pllor phes of chis axudy, which is a survey of trace elconte in warket ailk collected in Califoraile and Colorado, teve been reported in Rof. 14. This turvey served a - focus for daveloping procedures for the sesay of trace elenents using Instrumental Reutron Activacion and $x$-ray fluorescence cechnfquas. Intercomparitions. latween the two techniqueo ware carried out as a velddation of the enalytical prom ceduren. Collection procedures were al ao tanted and valfdated during the course of the scudy. 


\section{References}

1. B.J. Roberts, Aerosul Trace Elegent Anolyats Using Neutron Actlvation and X-Ray Eluoregcence. Lawence Liveraore Laboracory, Rept. UCRL-51499 (1974).

2. Characterlzation of Aerosole in Californla - Flnal Report. Rockwell tnternut lonat Sclence Center, Rept. SC524,25FR (1974).

3. W.J. Stlver, C.L. Indeken, J.W. Meadows, E.H. Willes, and D.R. McIntyre, Environ:mental Monitortiv at the Lanrence Livercore Lboratory. 1974 Annual Reporc. UCRL-50027 (1974).

4. W.J. Richards, Uacr's Guide - Livarnore Pool-Type Reaceor, Laurence Liverwore Laboracory Manual M-051 (1974).

5. W. E. Nervik and Roger Ray, Enguetak Radjolorical Survey. United States Energy Regearch and Development idminisiration, Nevade Operationa Office, Las Vegat, Yevada, Yol. I NVo-140 (19:3).

6. H.R. Ralston, and G.E. W1lcox, A Conputer Mechod of Peak Area Deteruinat fons fron Ge(Li) Gaman Spectr., Lawrence Livermore Laboratory Rept, UCRL-71210 Preprint (1968).

7. R. Cunnink ond J.B. NLday. Copputertzed Quantitative Analysis By Gaman-Ray Spectronetry, Vol. I - Descrintion of the GaMANal. Program, Lawtence Livermore Laboratory Rept. UCRL-51061 Vol. I (1972).

8. J.M. Ondov, W.H. Zoller, T. Olaez, N.K. Aras, G.E. Gondon, L.A. Rancitall1, K.H. Abel, R.H. Fliby, K.R. Shah, and R.C. Ragaini, "Elenental Concentrations in the Nat lonal Buresu of Standards' Enviromantal Coal and Fly Ash Standara Reference Macer1als," Analyetcal Chemiatry, 47 1102 (1975).

9. D.C. Casp, J.A, Cooper, and J.R. Rhodes, "Z-Ray Fluorescence Analysis - Results of a First Round Intercomparison Study." X-Ray Spectromerry 3, (Jan, 1974).

10. R.C. Regain1, H.R. Ralston, D. Garvis, and R. Kaifer, Trace Elementa in Cal fornia Aerogols. Part I, Lawrence Livertore loboratory Rept, UCRL-51850 (1975).

11. R.C. Ragaini, H.R, Ralaton, A.L. Langhorat, and D. Garv1s, Enuitonmental Trace Metal Concaminecion In Kollog, Idaro Near Z1nc and Lead Smelters, presented at the 30th Annual Northweat Rogional Meering, American Chemical Soctery, Honolulu, Hewa11, June 1975; Letrence LIvermore Laboratory Rept. UCRL-76735 (1975).

12. R.E, Heft, W.A. Phillips, H.R, Ralgcon, and W.A. Steale, "Radlonuc ilde Transport Studfes in the Hubolt Boy Marine Enviroment," Rad Loactive Concmination of the Marine Environent, IARA-SM-158/37, V1enna (1973).

13. G. Pofley, Lawrence Livermore Laboratory, private comunication (1975).

14. R.C. Ragain1, A.L. Langhorat, H.R. Raleton, end R. Heft, Ingtrumental Trace Element Anslyole of Caldfornis Markat Milk, Lawence Livernore Labaratory Rept. UCRL-51859 (1975).

TAL./grw 